\title{
Risk factors for subsequent endocrine-related cancer in childhood cancer survivors
}

\author{
M Wijnen1,2, M M van den Heuvel-Eibrink1,3, M Medici2,4, R P Peeters 2,4 , \\ A J van der Lely2 and S J C M M Neggers 1,2
}

1Department of Pediatric Oncology/Hematology, Erasmus MC - Sophia Children's Hospital, Rotterdam, the Netherlands

2Department of Medicine, Section Endocrinology, Erasmus University Medical Center, Rotterdam, the Netherlands ${ }^{3}$ Princess Maxima Center for Pediatric Oncology, Utrecht, the Netherlands

4Rotterdam Thyroid Center, Erasmus University Medical Center, Rotterdam, the Netherlands
Correspondence should be addressed to M Wijnen

Email

m.wijnen.1@erasmusmc.nl

\begin{abstract}
Long-term adverse health conditions, including secondary malignant neoplasms, are common in childhood cancer survivors. Although mortality attributable to secondary malignancies declined over the past decades, the risk for developing a solid secondary malignant neoplasm did not. Endocrine-related malignancies are among the most common secondary malignant neoplasms observed in childhood cancer survivors. In this systematic review, we describe risk factors for secondary malignant neoplasms of the breast and thyroid, since these are the most common secondary endocrine-related malignancies in childhood cancer survivors. Radiotherapy is the most important risk factor for secondary breast and thyroid cancer in childhood cancer survivors. Breast cancer risk is especially increased in survivors of Hodgkin lymphoma who received moderate- to high-dosed mantle field irradiation. Recent studies also demonstrated an increased risk after lowerdose irradiation in other radiation fields for other childhood cancer subtypes. Premature ovarian insufficiency may protect against radiation-induced breast cancer. Although evidence is weak, estrogen-progestin replacement therapy does not seem to be associated with an increased breast cancer risk in premature ovarian-insufficient childhood cancer survivors. Radiotherapy involving the thyroid gland increases the risk for secondary differentiated thyroid carcinoma, as well as benign thyroid nodules. Currently available studies on secondary malignant neoplasms in childhood cancer survivors are limited by short follow-up durations and assessed before treatment regimens. In addition, studies on risk-modifying effects of environmental and lifestyle factors are lacking. Risk-modifying effects of premature ovarian insufficiency and estrogen-progestin replacement therapy on radiation-induced breast cancer require further study.
\end{abstract}
Key Words
- childhood cancer survivors
- secondary malignant neoplasms
- endocrine-related cancer
- breast cancer
- thyroid cancer

\section{Introduction}

Childhood cancer survival has increased substantially over the past five decades due to advances in therapy, risk-based treatment stratification, and supportive care (Hudson et al. 2014). To date, approximately $80 \%$ of children and adolescents survive at least 5 years following a diagnosis of childhood cancer (Gatta et al. 2014, Howlader et al. 2015), and are thereby subsequently considered childhood cancer survivors. This percentage is anticipated to grow

Published by Bioscientifica Ltd
Endocrine-Related Cancer (2016) 23, R299-R321 
due to further improvements in childhood cancer care (Hudson et al. 2014), and a slow increase in childhood cancer incidence as reported by some investigators (Siegel et al. 2014, Steliarova-Foucher et al. 2004). Accordingly, awareness of and insight in side effects and long-term consequences of childhood cancer treatment have become increasingly important (Hewitt et al. 2003, Oeffinger et al. 2006, Geenen et al. 2007, Armstrong et al. 2009, Hudson et al. 2013, Hjorth et al. 2015). At an attained age of 45 years, approximately $95 \%$ of childhood cancer survivors suffer from at least one chronic health condition related to their former cancer treatment; in approximately $75 \%$, this concerns a serious/disabling or life-threatening condition (Hudson et al. 2013). Over the past decades, childhood cancer treatment protocols have been modified, aiming to reduce the occurrence and severity of long-term treatment-related complications. Recently, Armstrong and coworkers demonstrated that these efforts resulted in improved long-term survival (Armstrong et al. 2016).

Secondary neoplasms are among the most serious long-term adverse health conditions in childhood cancer survivors, and can be defined as histologically distinct tumors developing after primary cancer therapy. They have been estimated to affect approximately $21 \%$ of childhood cancer survivors after 30 years of follow-up since primary cancer diagnosis (Friedman et al. 2010). This estimation includes both benign and malignant secondary neoplasms. The 30-year cumulative incidence of secondary malignant neoplasms solely is approximately $8 \%$, and represents a six-fold increased risk in comparison with the general population (Friedman et al. 2010). The increased risk for secondary malignancies in childhood cancer survivors seems to persist even after 40 years of follow-up since primary cancer diagnosis (Olsen et al. 2009). At an attained survivor's age of 60 years, the cumulative incidence of secondary malignant neoplasms varies between 14 and 18\% (Olsen et al. 2009, Reulen et al. 2011). The risk for secondary malignant neoplasms in older childhood cancer survivors remains unknown. Although most secondary malignant neoplasms are diagnosed during the first 10-20 years following childhood cancer treatment (Friedman et al. 2010, Choi et al. 2014), they may present within months to decades following the completion of former cancer therapy (Choi et al. 2014). Risk factors for the development of secondary malignancies in childhood cancer survivors include host factors, primary cancer diagnosis, types and timing of primary cancer treatment, environmental factors, and lifestyle factors ( $\mathrm{Ng}$ et al. 2010). Secondary malignant neoplasms appear to be an important cause of death in childhood cancer survivors. Recent cohort studies demonstrated that $12-19 \%$ of mortality in individuals who survived at least 5 years following a diagnosis of childhood cancer was attributable to secondary malignancies (Mertens et al. 2008, Reulen et al. 2010, Garwicz et al. 2012). After 25 years of follow-up since primary cancer diagnosis, secondary malignant neoplasms even become the most important cause of death in survivors of childhood cancer (Mertens et al. 2008, Reulen et al. 2010). Although mortality attributable to secondary malignancies in childhood cancer survivors declined over the past treatment eras (Armstrong et al. 2016), the risk for developing a solid secondary malignant neoplasm did not (Schaapveld et al. 2015). Endocrine-related cancers are among the most common secondary malignancies in childhood cancer survivors (Inskip \& Curtis 2007, Olsen et al. 2009, Friedman et al. 2010, Reulen et al. 2011). In the Childhood Cancer Survivor Study, they represent $40 \%$ of the invasive

\section{A Subsequent malignant neoplasms}

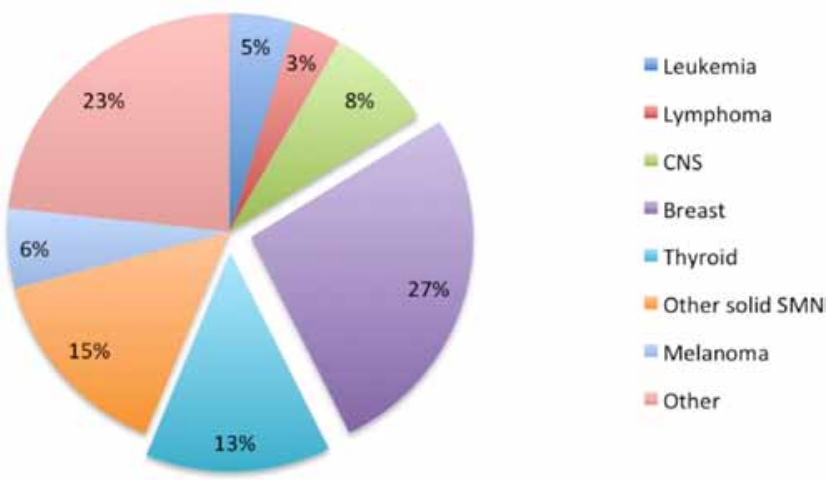

B Primary cancer diagnosis

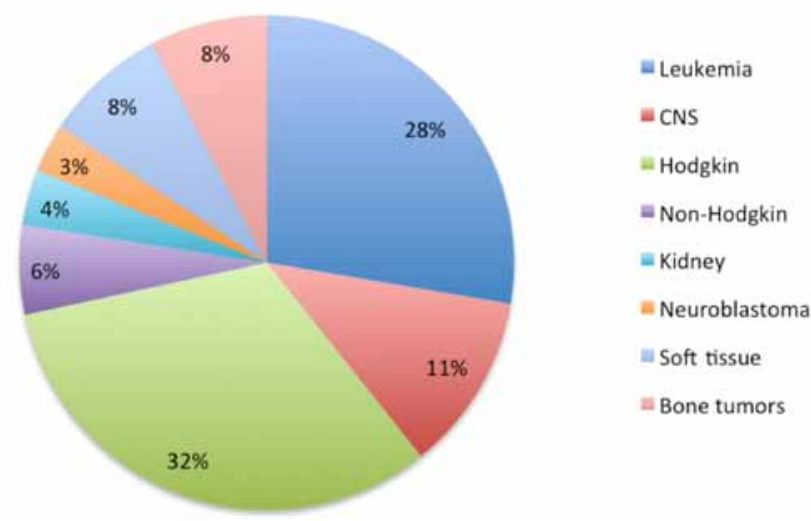

Figure 1

Distribution of secondary malignant neoplasms and primary cancer diagnoses among childhood cancer survivors who developed a secondary neoplasm as observed in the Childhood Cancer Survivor Study by Friedman et al. (2010). (A) Secondary malignant neoplasms (nonmelanoma skin cancers excluded). (B) Primary cancer diagnoses. CNS, central nervous system; SMN, secondary malignant neoplasm.

Published by Bioscientifica Ltd. 
secondary malignant neoplasms observed (Fig. 1A) (Friedman et al. 2010).

In this review, we will discuss risk factors for secondary endocrine-related malignant neoplasms in childhood cancer survivors. A special focus will be on breast and thyroid cancer, since these are the most common secondary endocrine-related malignancies in survivors of childhood cancer (Olsen et al. 2009, Friedman et al. 2010, Reulen et al. 2011).

\section{Search strategy}

We systematically searched the MEDLINE-database (United States National Library of Medicine, Washington, DC, USA) until January 2016 for relevant articles on secondary cancer risk in survivors of pediatric malignancies. The keywords 'childhood cancer survivors', 'second malignant neoplasms', 'secondary malignant neoplasms', 'subsequent neoplasms', 'endocrine cancers', 'breast cancer', 'thyroid cancer', 'risk factors', 'radiotherapy', 'radiation', 'irradiation', 'chemotherapy', 'stem cell transplantation', 'total body irradiation', 'conformal radiotherapy', 'intensitymodulated radiation therapy' and 'proton-beam therapy' were used. Only articles written in English were included in the review. Reference lists of included articles were checked for additional relevant publications. In case two or more articles described the same patient cohort, the most recent or relevant article was included.

\section{Risk factors for secondary malignant neoplasms in childhood cancer survivors}

In the Childhood Cancer Survivor Study, host-, diseaseand treatment-related risk factors for the development of secondary neoplasms in childhood cancer survivors have been identified (Friedman et al. 2010). The Childhood Cancer Survivor Study is a multi-institutional study conducted in the United States and Canada, and involves 14,363 individuals treated for cancer $<21$ years of age (Robison et al. 2002). Female gender and older age at initial cancer diagnosis were associated with an increased risk for secondary malignant neoplasms after childhood cancer (relative risk (RR) 1.4 (95\% confidence interval (CI): 1.2-1.6) for females vs males; RR 1.5 (95\% CI: $1.2-1.9)$ for age at diagnosis $\geq 15$ years vs 0-4 years) (Friedman et al. 2010). The Surveillance,

Table 1 High-penetrance genetic cancer predisposition syndromes associated with endocrine-related malignancies.

Name

Hereditary breast and ovarian cancer syndrome

Cowden syndrome (also known as

multiple hamartoma syndrome)

Li-Fraumeni syndrome (LFS)

Hereditary diffuse gastric cancer

Peutz-Jeghers syndrome

Multiple endocrine neoplasia type 1

(MEN1)

Multiple endocrine neoplasia type 2

(MEN2)

Succinate dehydrogenase complex (SDHX) SDHB

von Hippel-Lindau syndrome (VHL) VHL

Adenomatous polyposis of the colon $\quad A P C$

Beckwith-Wiedemann syndrome

DICER1 syndrome
SDHC

SDHD

Genes
BRCA1

BRCA2

PTEN

TP53

$\mathrm{CDH1}$

STK 11

MEN1

RET

CDKN1C/NSD1

DICER1

Associated cancers
Breast cancer, ovarian cancer, prostate cancer,
pancreatic cancer, biliary cancer, melanoma

\section{References}

Shiovitz \& Korde (2015) pancreatic cancer, biliary cancer, melanoma

Breast cancer, nonmedullary thyroid cancer, endometrial cancer, genitourinary tumors

Breast cancer, sarcoma, brain tumor, adrenocortical tumor, leukemia, lung cancer Breast cancer, gastric cancer, colorectal cancer Gastro-intestinal cancer, breast cancer, ovarian cancer, pancreatic cancer

Parathyroid adenoma, pancreatic endocrine tumors, pituitary adenoma

Medullary thyroid carcinoma, pheochromocytoma, parathyroid hyperplasia

Paraganglioma, pheochromocytoma

Pilarski \& Nagy (2012),

Shiovitz \& Korde (2015)

Shiovitz \& Korde (2015)

Shiovitz \& Korde (2015)

Shiovitz \& Korde (2015),

Strahm \& Malkin (2006)

Pilarski \& Nagy (2012),

Strahm \& Malkin (2006)

Pilarski \& Nagy (2012),

Strahm \& Malkin (2006)

Pilarski \& Nagy (2012)

Retinal and central nervous system

Pilarski \& Nagy (2012) hemangioblastoma, renal cell carcinoma, pheochromocytoma, pancreatic islet cell tumor, endolymphatic sac tumor

Colon cancer, small intestine cancer, thyroid cancer, stomach cancer, hepatoblastoma

Nephroblastoma, hepatoblastoma, adrenal carcinoma, rhabdomyosarcoma

Pleuropulmonary blastoma, ovarian tumor, cystic nephroma, sarcoma, thyroid tumor, pituitary tumor
Strahm \& Malkin (2006)

Strahm \& Malkin (2006)

Foulkes et al. (2014) 
Epidemiology, and End Results (SEER) program of the National Cancer Institute (NCI) of the United States could not demonstrate this sex difference in the risk for secondary malignant neoplasms. However, it found a somewhat higher risk for secondary malignancies in black vs white people (standardized incidence ratio (SIR) 8.9 vs SIR 5.5; excess absolute risk (EAR) 18.4 vs 15.0 per 10,000 person-years) (Inskip \& Curtis 2007). Genetic susceptibility might contribute to the development of secondary neoplasms in childhood cancer survivors, which is illustrated by high-penetrance genetic cancer predisposition syndromes (Table 1) (Strahm \& Malkin 2006, Pilarski \& Nagy 2012, Foulkes et al. 2014, Shiovitz $\&$ Korde 2015). However, germline mutations in known moderate- to high-penetrance cancer susceptibility genes are only found in $8.5 \%$ of pediatric and adolescent cancer patients (Zhang et al. 2015). Data from the Swedish general population suggest that less pathogenic low-penetrance familial cancer predisposition might be more important in the development of malignancies than high-penetrance genetic cancer susceptibility genes (Frank et al. 2015). This is illustrated by Friedman and coworkers, who observed an increased cancer risk in siblings of childhood cancer survivors in comparison with the general population (SIR 1.5 (95\% CI: 1.3-1.7)), even after exclusion of families with suspected highpenetrance genetic cancer predisposition syndromes (SIR 1.3 (95\% CI: 1.2-1.5)) (Friedman et al. 2005). In their study, siblings and offspring of childhood cancer survivors who developed a secondary malignant neoplasm were even at higher risk of developing cancer in comparison with relatives of childhood cancer survivors who did not develop a secondary malignancy (SIR 2.4 (95\% CI: 1.5-3.7) for siblings; SIR 15.0 (95\% CI: 5.3-42.9) for offspring) (Friedman et al. 2005).

Childhood cancer survivors at highest risk for secondary malignant neoplasms include survivors of Hodgkin lymphoma, leukemia, sarcoma, and central nervous system malignancies (Fig. 1B) (Inskip \& Curtis 2007, Friedman et al. 2010, Reulen et al. 2011). This seems to be related to administered treatment modalities. Radiotherapy is the most important risk factor for the development of secondary neoplasms (Inskip \& Curtis 2007, Friedman et al. 2010, Reulen et al. 2011). Risk for radiation-induced secondary malignant neoplasms depends on cumulative radiation dose, radiotherapy fractionation, radiation field, radiosensitivity, radiotherapy technique, quality of radiation, and other confounding factors (Kumar 2012). Besides radiotherapy, chemotherapeutic agents

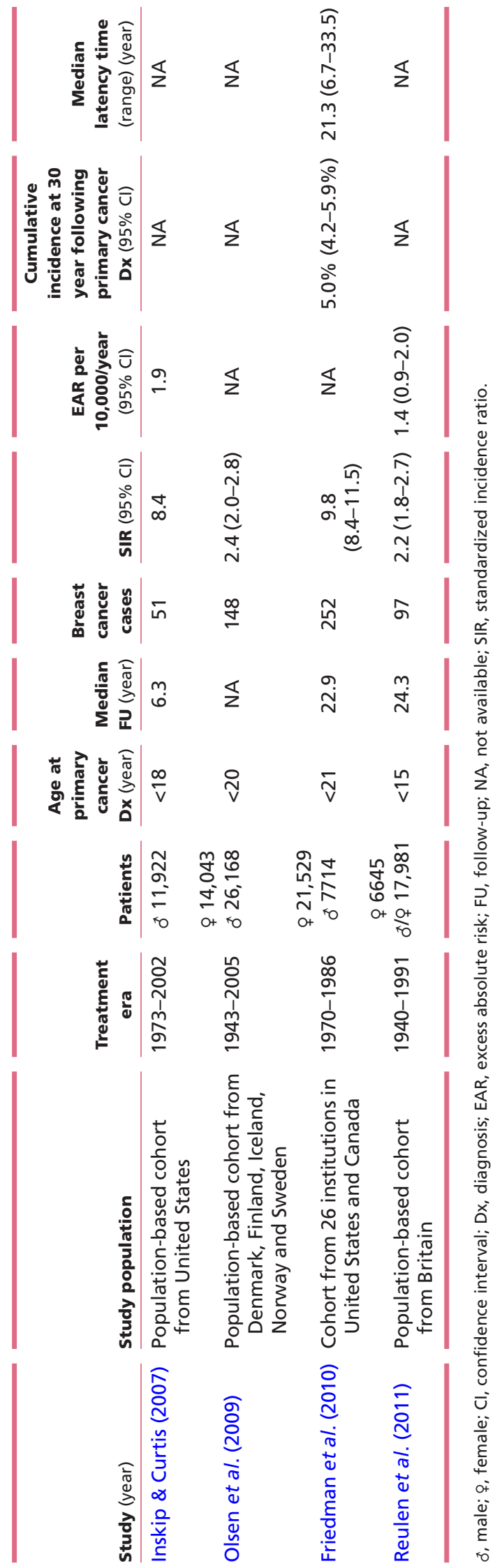

Published by Bioscientifica Ltd 


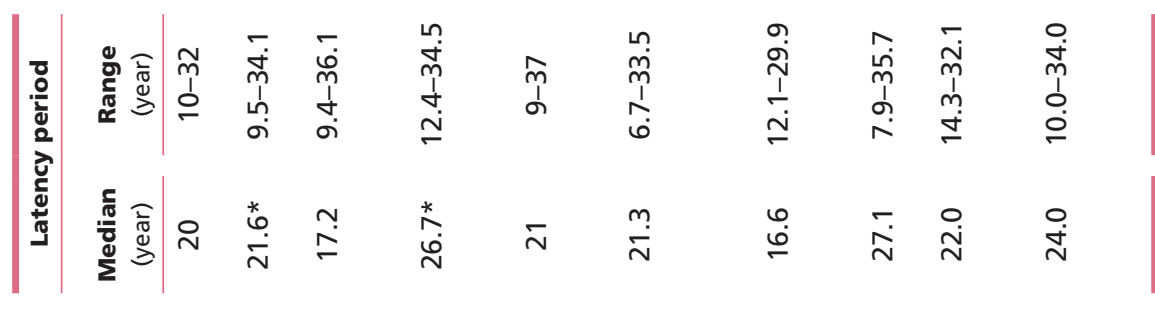
Iี

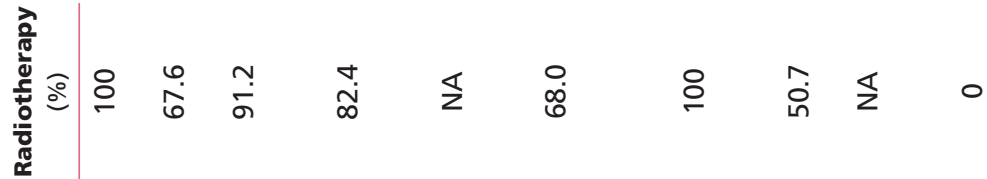

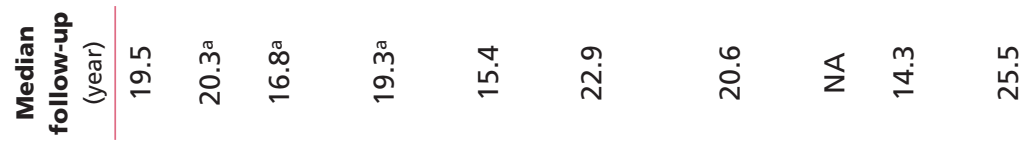

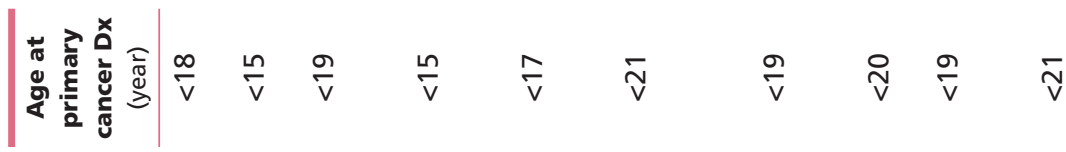

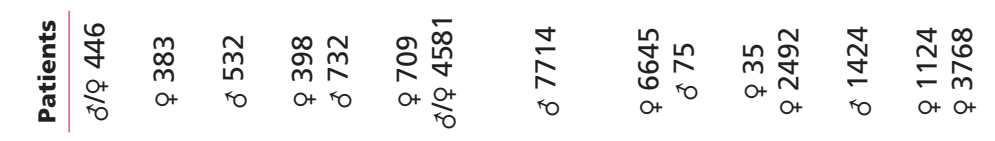

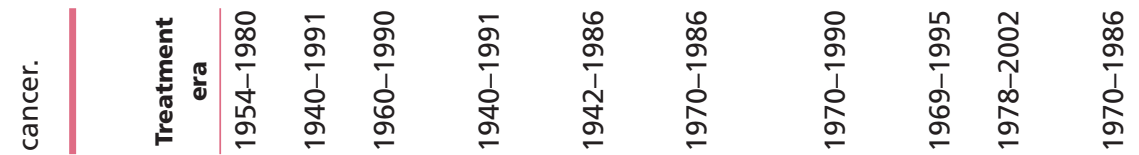

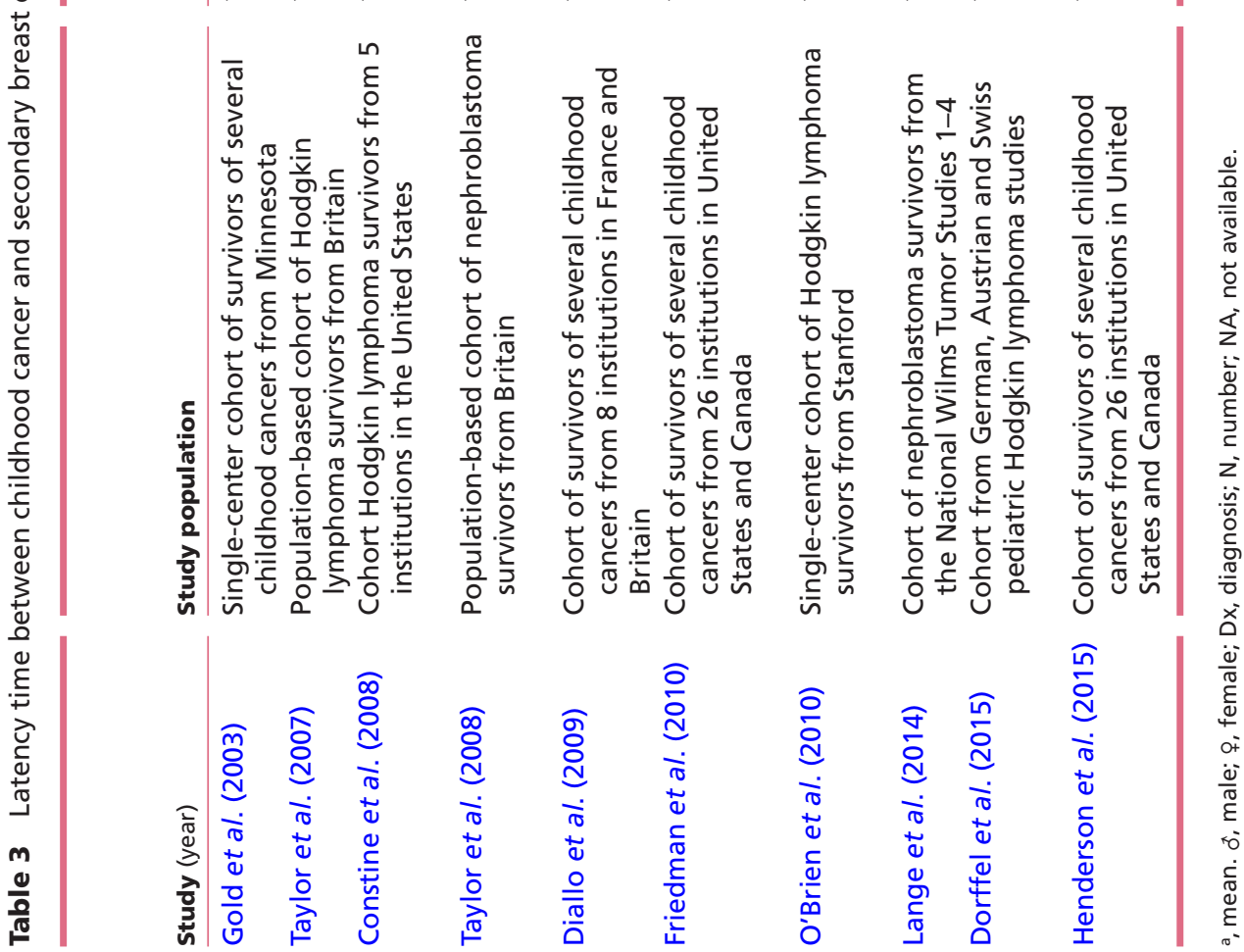


(i.e. alkylators, anthracyclines, and topoisomerase II inhibitors), as well as hematopoietic stem cell transplantation, have been associated with an increased risk for secondary malignant neoplasms in childhood cancer survivors (Meadows et al. 2009, Socie et al. 2012, Choi et al. 2014).

Besides the factors mentioned above, environmental and lifestyle determinants may also be important in secondary tumor development (Travis et al. 2002, Carpenter \& Bushkin-Bedient 2013, Kamiya et al. 2015). However, studies specifically addressing the riskmodifying effects of these determinants in childhood cancer survivors have to be performed yet.

\section{Breast cancer}

\section{Epidemiology and host-related risk factors}

Breast cancer risk in childhood cancer survivors has recently been addressed in several large cohort studies (Table 2) (Inskip \& Curtis 2007, Olsen et al. 2009, Friedman et al. 2010, Reulen et al. 2011). After 30 years of follow-up since childhood cancer diagnosis, secondary breast cancer affects approximately 5\% of childhood cancer survivors (Friedman et al. 2010). This represents a standardized incidence ratio of 2.2-9.8 in comparison with the general population (Inskip \& Curtis 2007, Olsen et al. 2009, Friedman et al. 2010, Reulen et al. 2011). Latency periods for the development of secondary breast cancer following childhood cancer vary between 6.7 and 39 years (average 21.8 years) (Table 3) (Gold et al. 2003, Taylor et al. 2007, 2008, Constine et al. 2008, Diallo et al. 2009, Friedman et al. 2010, O'Brien et al. 2010, Lange et al. 2014, Dorffel et al. 2015, Henderson et al. 2015). This is illustrated by Reulen and coworkers, who observed an increased risk for secondary breast cancer in female childhood cancer survivors during the first three decades following primary cancer diagnosis, which gradually declined to general population norms at an attained survivor's age of 50 years (Reulen et al. 2008).

Several studies identified pubertal age at primary cancer diagnosis to be an important risk factor for secondary breast cancer (Metayer et al. 2000, Constine et al. 2008, Inskip et al. 2009). In a study by Metayer and coworkers, risk for secondary breast cancer was highest in women aged 10-16 years at Hodgkin lymphoma diagnosis (Metayer et al. 2000). In addition, 114 of the 120 secondary breast cancers observed in a study by Inskip and coworkers were diagnosed in women aged 10-20 years at childhood cancer diagnosis (Inskip et al . 2009). Therefore, an increased susceptibility of proliferating breast tissue for carcinogenic factors in adolescent girls
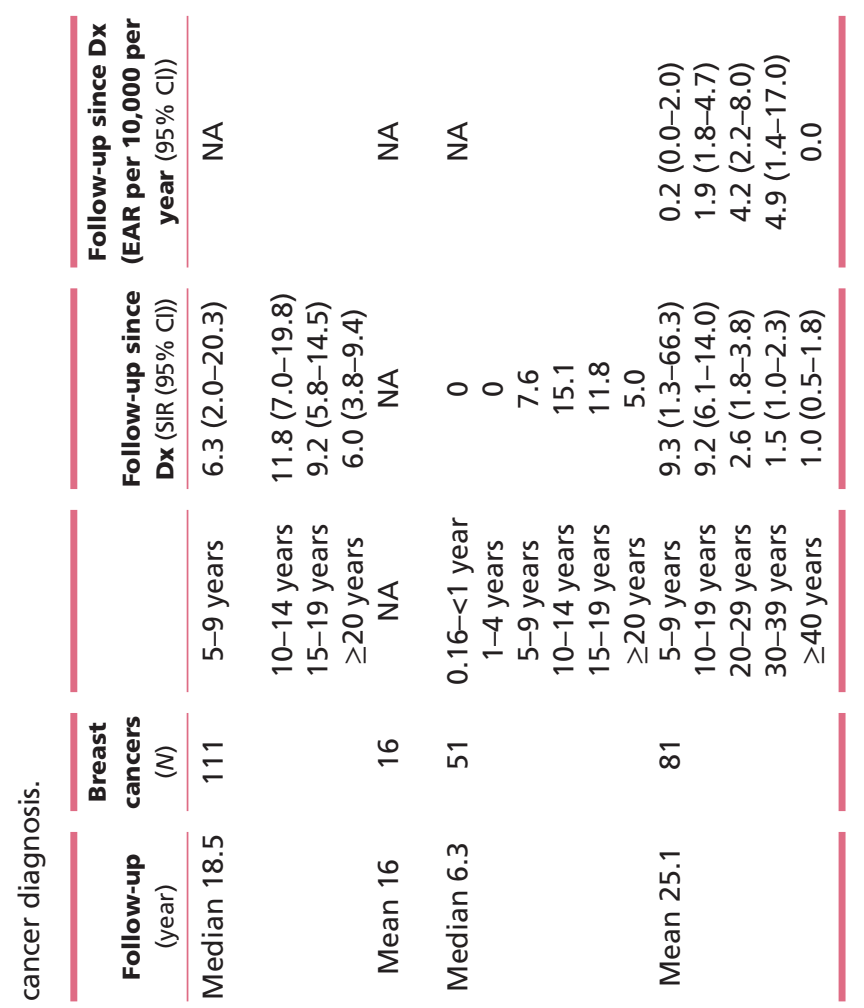

$\div$ in

$\bar{\infty}$

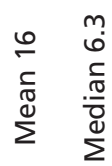

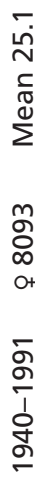

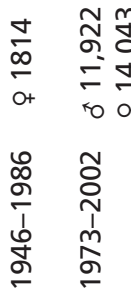


has been suggested (Metayer et al. 2000, Inskip et al. 2009, Barcellos-Hoff 2013). However, several other studies could not confirm a risk-modifying effect of age at childhood cancer diagnosis (Travis et al. 2003, Guibout et al. 2005, Reulen et al. 2008). This inconsistency might be explained by shorter follow-up durations since childhood cancer in studies reporting an increased secondary breast cancer risk by pubertal age compared with studies not reporting such an effect (average 11.0-16.8 vs 16-25.1 years) (Metayer et al. 2000, Guibout et al. 2005, Constine et al. 2008, Reulen et al. 2008). Secondary breast cancer risk in childhood cancer survivors by follow-up since childhood cancer diagnosis, attained survivor's age and age at childhood cancer diagnosis is represented in Tables 4 and 5 (Kenney et al. 2004, Guibout et al. 2005, Inskip \& Curtis 2007, Reulen et al. 2008).

Genetic susceptibility might contribute to secondary breast cancer development in childhood cancer survivors. This is illustrated by studies reporting an increased secondary breast cancer risk in survivors of childhood cancer with a positive family history for breast and/or ovarian cancer (Kenney et al. 2004, Hill et al. 2005). However, germline mutations in known high- to moderate-penetrance breast cancer susceptibility genes like BRCA1, BRCA2, TP53 and ATM are only found in a minority of childhood cancer survivors who develop a secondary breast malignancy (Broeks et al. 2000, Nichols et al. 2003). Therefore, less pathogenic low-penetrance genetic susceptibility might be more important. Recent studies identified allelic variants in PRDM1 and FGFR2 to predispose Hodgkin lymphoma survivors to radiationinduced breast cancer (Best et al. 2011, Ma et al. 2012).

Kenney and coworkers identified the presence of thyroid disease to be a risk factor for secondary breast cancer in childhood cancer survivors (RR 1.7 (95\% CI: 1.1-2.6)) (Kenney et al. 2004). An association between thyroid disease and breast cancer has also been observed in the general population (Hardefeldt et al. 2012, Prinzi et al. 2014). Although no clear explanations for this finding have been found, stimulation of breast cancer cells by deregulated thyroid hormone receptors, estrogenreceptor activation by triiodothyronine, and a potential role of the sodium-iodide symporter expressed in breast cancer tissue have been proposed (Nogueira \& Brentani 1996, Silva et al. 2002, Portulano et al. 2014).

\section{Treatment-related risk factors for secondary breast cancer}

Radiotherapy Chest irradiation is the most important treatment-related risk factor for secondary breast cancer in
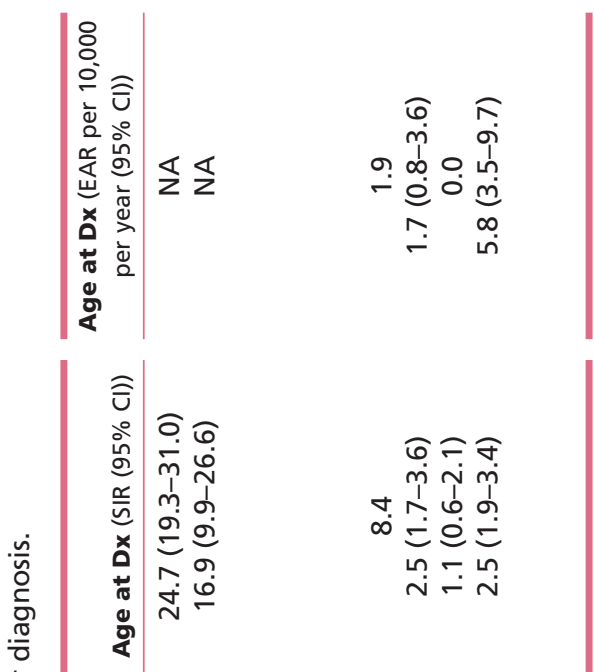


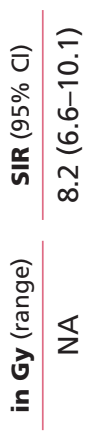

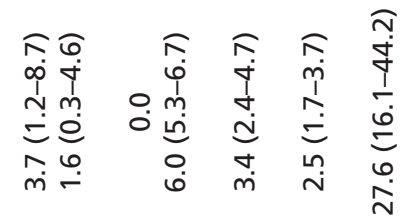

$\infty \stackrel{m}{\frac{m}{m}} \stackrel{m}{m} \mathbb{m}$
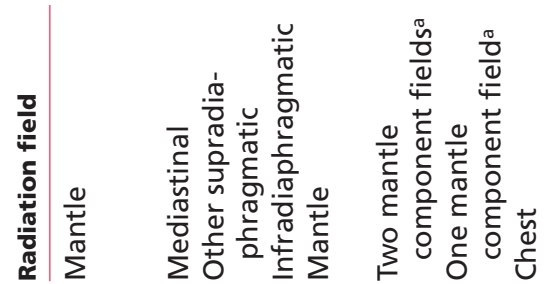

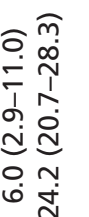

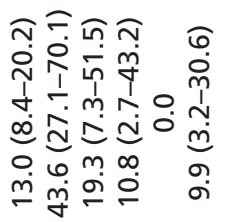

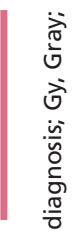

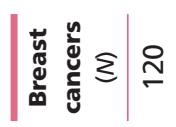

$\stackrel{m}{m}$

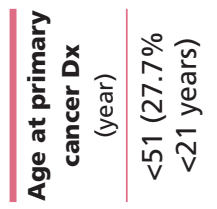

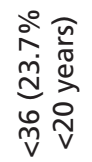

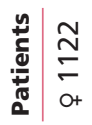

ํํำ

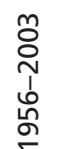

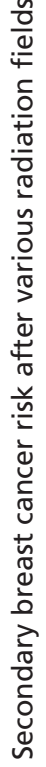

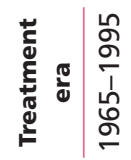

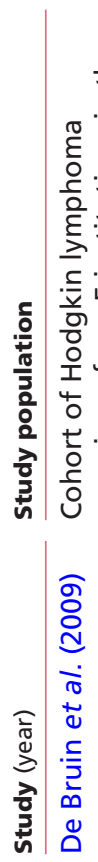

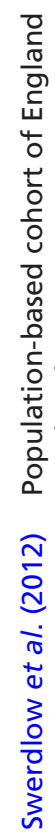

http://erc.endocrinology-journals.org DOI: 10.1530/ERC-16-0113

2016 Society for Endocrinology Printed in Great Britain

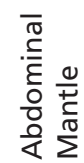

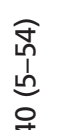

$\stackrel{\infty}{\sim} \quad \stackrel{m}{\sim}$

$\stackrel{\sim}{\mathcal{V}} \quad \bar{v}$

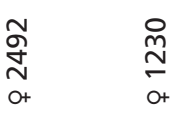

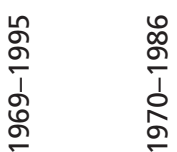

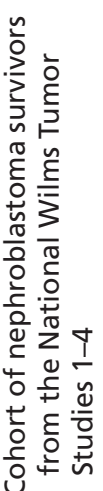

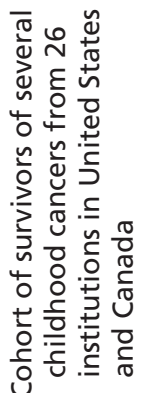

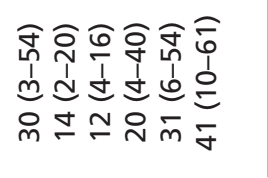

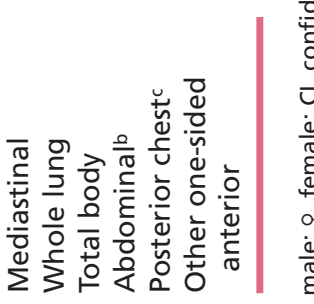

2

$\bar{N}$

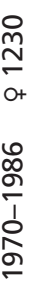

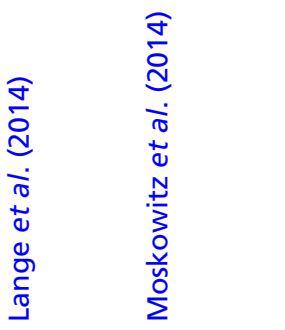

$\mid \frac{9}{2}$

年

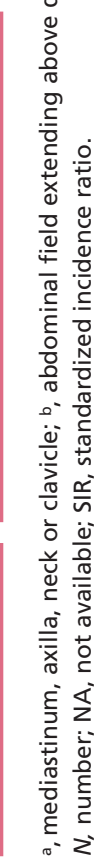


childhood cancer survivors. In a recent review, Henderson and coworkers summarized the risk for secondary breast cancer after treatment with chest irradiation for pediatric cancer (Henderson et al. 2010). In the included higher quality cohort studies, standardized incidence ratios for secondary breast cancer varied between 13.3 and 55.5, excess absolute risks varied between 18.6 and 79.0 per 10,000 person-years, and cumulative incidences varied between 12 and $26 \%$ at 25-30 years follow-up since childhood cancer (Ng et al. 2002, Bhatia et al. 2003, Kenney et al. 2004, Taylor et al. 2007, Constine et al. 2008, De Bruin et al. 2009). These risk estimates are comparable to risks for breast cancer in women harboring a germline BRCA1 or BRCA2 gene mutation (Moskowitz et al. 2014).

Radiation fields associated with an increased secondary breast cancer risk in childhood cancer survivors include mantle field, whole lung, hemithorax, mediastinum, supradiaphragmatic abdomen, axilla, neck and clavicle, as well as total body (Table 6) (De Bruin et al. 2009, Swerdlow et al. 2012, Lange et al. 2014, Moskowitz et al. 2014). Smaller radiation fields seem to be associated with lower risks for radiation-induced breast cancer (De Bruin et al. 2009, Swerdlow et al. 2012, Schaapveld et al. 2015). However, despite an increased use of less extensive supradiaphragmatic radiation fields over the past decades, the incidence of radiation-induced breast cancer remained stable in Hodgkin lymphoma survivors (Schaapveld et al. 2015). This may be partly related to an earlier detection of secondary breast malignancies by improved screening practices (Ng et al. 2013). In a recent study on secondary breast cancer risk after craniospinal irradiation for pediatric central nervous system malignancies and leukemia, Moskowitz and coworkers observed an increased risk for secondary breast cancer in the subgroup of leukemia survivors solely (SIR 3.8 (95\% CI: 1.2-11.7)) (Moskowitz et al. 2015). This observation might be related to genetic susceptibility, as illustrated by a population-based study in Italy that observed an increased standardized mortality ratio attributable to breast cancer in mothers of children diagnosed with leukemia (Zuccolo et al. 2007).

The relationship between chest radiation dose and breast cancer risk has been investigated by several studies (Table 7) (Travis et al. 2003, van Leeuwen et al. 2003, Guibout et al. 2005, Hill et al. 2005, Inskip et al. 2009). A linear dose-response curve has been established (Fig. 2A) (Inskip et al. 2009, Berrington de Gonzalez et al. 2013). Risk for radiation-induced breast cancer was traditionally studied after moderate- to high-dosed chest irradiation (i.e. $\geq 20$ Gy) (Henderson et al. 2010). However, recent studies also demonstrated an increased secondary breast cancer risk after lower dosed chest irradiation (Lange et al. 2014, Moskowitz et al. 2014). Lange and coworkers observed an increased breast cancer risk of $14.4 \%$ (95\% CI: 7.6-30.1) at an attained survivors' age of 40 years after 1-12 Gy chest irradiation for nephroblastoma (Lange et al. 2014). In a recent study by Moskowitz and coworkers, breast cancer risk was 30.6-fold increased (95\% CI: 18.4-50.7) in comparison with the United States general

Table 7 Estimated excess relative risk for secondary breast cancer per Gy chest irradiation in childhood cancer survivors.

\begin{tabular}{|c|c|c|c|c|c|}
\hline Study (year) & Study population & $\begin{array}{c}\text { Treatment } \\
\text { era }\end{array}$ & Patients ${ }^{a}$ & $\begin{array}{l}\text { Age at primary } \\
\text { cancer Dx } \\
\text { (year) }\end{array}$ & $\begin{array}{l}\text { ERR for subsequent } \\
\text { breast cancer per } \\
\text { Gy }(95 \% \mathrm{Cl})\end{array}$ \\
\hline \multirow[t]{2}{*}{ Travis et al. (2003) } & $\begin{array}{l}\text { Nested case-control study in a cohort of } \\
\text { Hodgkin lymphoma survivors from } 6 \\
\text { population-based cohorts }\end{array}$ & 1965-1994 & Cases 105 & $<31$ & $0.15(0.04-0.73)$ \\
\hline & & & Controls 266 & & \\
\hline \multirow[t]{2}{*}{$\begin{array}{l}\text { van Leeuwen et al. } \\
\text { (2003) }\end{array}$} & $\begin{array}{l}\text { Nested case-control study in a cohort of } \\
\text { Hodgkin lymphoma survivors from } 4 \\
\text { institutions in the Netherlands }\end{array}$ & 1965-1988 & Cases 48 & $<41$ & $0.03(0.002-0.06)$ \\
\hline & & & Controls 175 & & \\
\hline Guibout et al. (2005) & $\begin{array}{l}\text { Cohort of solid tumor survivors from } 8 \\
\text { institutions in France and Britain }\end{array}$ & 1946-1986 & 1814 & $<17$ & $0.13(<0.00-0.75)$ \\
\hline \multirow[t]{2}{*}{ Hill et al. (2005) } & $\begin{array}{l}\text { Nested case-control study in } 6 \text { population- } \\
\text { based cohorts of Hodgkin lymphoma } \\
\text { survivors }\end{array}$ & 1965-1999 & Cases 105 & $<31$ & $1.04(1.00-1.07)^{b}$ \\
\hline & & & Controls 266 & & \\
\hline \multirow[t]{2}{*}{ Inskip et al. (2009) } & $\begin{array}{l}\text { Nested case-control study in a cohort of } \\
\text { survivors of several childhood cancers from } \\
26 \text { institutions in United States and Canada }\end{array}$ & 1970-1986 & Cases 120 & $<21$ & $0.36(0.14-0.93)$ \\
\hline & & & Controls 464 & & \\
\hline
\end{tabular}

a, all patients were females. ${ }^{\text {, }}$, relative risk per Gy. Cl, confidence interval; Dx, diagnosis; ERR, excess relative risk.

http://erc.endocrinology-journals.org DOI: 10.1530/ERC-16-0113
(ㄷ) 2016 Society for Endocrinology Printed in Great Britain
Published by Bioscientifica Ltd 

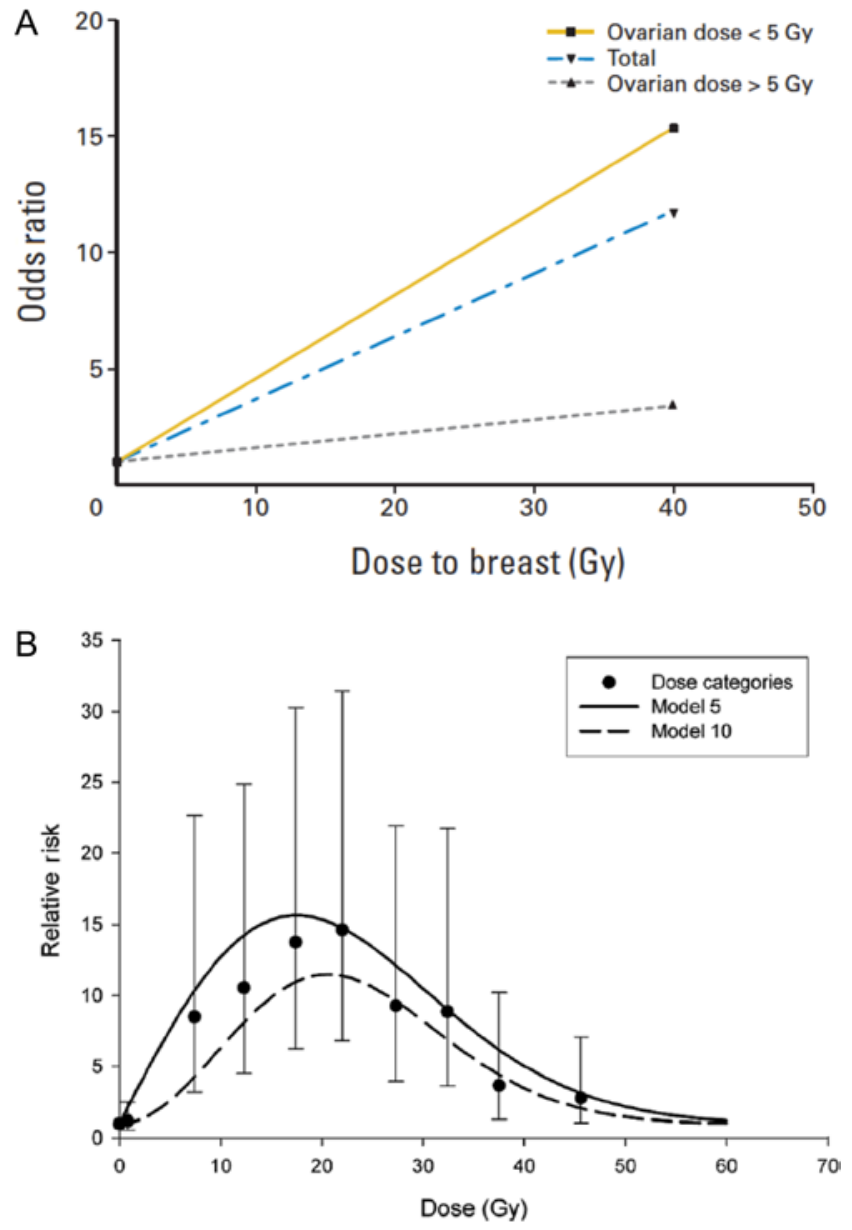

Figure 2

Fitted radiation dose-response relationships for chest irradiation and breast cancer, as well as thyroid gland irradiation and thyroid cancer as observed as in the Childhood Cancer Survivors Study by Inskip et al. (2009) and Bhatti et al. (2010), respectively. (A) Fitted dose-response relationship between chest radiation and breast cancer risk by radiation dose to the chest and ovaries. Reproduced from Inskip PD et al.: Journal of Clinical Oncology Vol. 27(24), 2009: 3901-3907. Reprinted with permission. Copyright 2009 American Society of Clinical Oncology. All rights reserved. (B) Fitted dose-response relationship for thyroid gland irradiation and thyroid cancer risk (based on two constructed models (model 5 and 10) and adjusted for attained age, gender, and primary childhood cancer subtype). Reproduced from Bhatti P et al.: Radiation Research Vol. 174(6), 2010: 741-752. Reprinted with permission. Copyright 2010 Radiation Research Society. All rights reserved.

population after 10-19 Gy chest irradiation for various childhood cancer subtypes (Moskowitz et al. 2014). Currently, there is no evidence of a significant effect of radiotherapy fractionation on secondary breast cancer risk following childhood cancer (Guibout et al. 2005).

Studies investigating radiation-related secondary cancer risk in childhood cancer survivors have predominantly assessed older radiotherapeutic modalities (Kumar 2012). Contemporary radiotherapeutic techniques like conformal radiotherapy, intensitymodulated radiation therapy and proton-beam therapy allow for more precise radiation delivery to the tumor target, thereby sparing healthy surrounding tissue. Therefore, these techniques may yield lower risks for secondary malignant neoplasm development compared with older radiotherapeutic modalities of earlier treatment eras (Armstrong et al. 2010, Kumar 2012). However, there are also concerns of a potentially increased secondary cancer risk following modern radiotherapeutic techniques due to a larger amount of leakage radiation (Kumar 2012). To our knowledge, observational studies on secondary breast cancer risk in childhood cancer survivors following modern radiotherapeutic techniques have to be performed yet.

\section{Hematopoietic stem cell transplantation}

Childhood cancer survivors who received hematopoietic stem cell transplantation are at increased risk for secondary breast cancer (Friedman et al. 2008, Danner-Koptik et al. 2013). Friedman and coworkers, observed a standardized incidence ratio of 2.2 (95\% CI: 1.7-2.9) for secondary breast cancer following allogeneic hematopoietic stem cell transplantation. In their study, secondary breast cancer risk was associated with total-body irradiation, follow-up duration, and age at stem cell transplantation (Friedman et al. 2008). In addition, Danner-Koptik and coworkers observed a standardized incidence ratio of 93 (95\% CI 11-336) for secondary breast cancer following autologous hematopoietic stem cell transplantation. However, they could not demonstrate an association between secondary breast cancer risk and age, gender, childhood cancer subtype, follow-up duration, response to primary cancer treatment, and use of total-body irradiation or etoposide as part of pretransplant conditioning regimen (DannerKoptik et al. 2013). Intriguingly, three cases of secondary breast cancer in male childhood cancer survivors following total-body irradiation and hematopoietic stem cell transplantation have been described (Latz et al. 2004, Lowe et al. 2008, O'Flynn et al. 2011).

Chemotherapy Most studies in cohorts of solely childhood cancer survivors and childhood- and adult-onset cancer survivors combined did not observe a relationship between chemotherapy and secondary breast cancer risk (Guibout et al. 2005, Reulen et al. 2008, Alm El-Din et al. 2009, Little et al. 2014), or observed a protective effect of certain chemotherapeutic agents on the development of radiation-related breast cancer (van Leeuwen et al. 2003,

Published by Bioscientifica Ltd 
Travis et al. 2003, 2005, De Bruin et al. 2009, Swerdlow et al. 2012, Schaapveld et al. 2015). However, two studies reported an increased risk for secondary breast cancer attributable to chemotherapy (Hancock et al. 1993, Henderson et al. 2015). In a combined cohort of childhood- and adult-onset Hodgkin lymphoma survivors, Hancock and coworkers observed a higher risk for secondary breast cancer following treatment with mechlorethamine, vincristine, procarbazine and prednisone in combination with radiotherapy compared with treatment with radiotherapy alone during the first 15 years following Hodgkin lymphoma (SIR 6.3 (95\% CI: 3.1-11.6) for combination chemoradiation therapy vs SIR 0.8 (95\% CI: 0.1-2.5) for radiotherapy alone). After 15 years of follow-up since Hodgkin lymphoma, secondary breast cancer risk became equivalently increased in both treatment groups (SIR 14.8 (95\% CI: 3.7-40.4) for combination chemoradiation therapy vs SIR 13.0 (95\% CI: 6.6-23.1) for radiotherapy alone) (Hancock et al. 1993). In addition, in a recent Childhood Cancer Survivor Study report by Henderson and coworkers on the risk for secondary breast cancer in childhood cancer survivors not treated with chest irradiation, exposure to anthracyclines and alkylating agents was associated with an increased secondary breast cancer risk (relative SIR 3.8 (95\% CI: 1.7-8.3) for anthracyclines dosed $\geq 250 \mathrm{mg} / \mathrm{m}^{2}$, and relative SIR 3.0 (95\% CI: $1.2-7.7$ ) for alkylating agents dosed $\geq 18,000 \mathrm{mg} / \mathrm{m}^{2}$ compared with no treatment with anthracyclines or alkylating agents) (Henderson et al. 2015). As suggested by Van Leeuwen and coworkers, the observed increased risk for secondary breast cancer attributable to anthracyclines and alkylating agents in childhood cancer survivors not treated with chest irradiation might be partly related to genetic susceptibility (van Leeuwen \& Ronckers 2016).

\section{Primary cancer diagnosis and secondary breast cancer risk}

In a series of three articles, Maule and coworkers reported standardized incidence ratios and excess absolute risks for secondary malignant neoplasms in childhood cancer survivors derived from 13 population-based cancer registries (Maule et al. 2007, 2008, 2011). They observed an increased risk for secondary breast cancer after several childhood cancer subtypes (Table 8). The highest risk for secondary breast cancer was observed in survivors of Hodgkin lymphoma (Maule et al. 2007), which likely reflect treatment with mantle field irradiation. However, Guibout and coworkers also observed an increased risk for secondary breast cancer in Hodgkin lymphoma survivors after adjustment for chest irradiation and
Table 8 Risk for secondary breast cancer by childhood cancer subtype.

\begin{tabular}{|c|c|c|}
\hline $\begin{array}{l}\text { Primary childhood cancer } \\
\text { diagnosis }\end{array}$ & SIR $(95 \% \mathrm{CI})$ & $\begin{array}{c}\text { EAR per } 100,000 \\
\text { person-years }\end{array}$ \\
\hline Leukemia & $2.42(0.06-13.5)$ & 0.8 \\
\hline Hodgkin lymphoma & $20.9(7.66-45.4)$ & 40.6 \\
\hline Non-Hodgkin lymphoma & $0.00(0.00-0.33)$ & -1.7 \\
\hline Glioma & $1.4(0.2-5.2)$ & 1.3 \\
\hline $\begin{array}{l}\text { Other central nervous } \\
\text { system tumors }\end{array}$ & $1.3(0.0-7.4)$ & 2.5 \\
\hline Retinoblastoma & $1.5(<0.1-8.5)$ & 1.6 \\
\hline Renal tumors & $3.0(0.1-16.7)$ & 2.7 \\
\hline Bone sarcomas & $6.8(1.9-17.5)$ & 26.9 \\
\hline Soft-tissue sarcomas & $1.3(<0.1-7.4)$ & 1.1 \\
\hline Epithelial tumors & $1.8(0.5-4.6)$ & 8.7 \\
\hline
\end{tabular}

$\mathrm{Cl}$, confidence interval; EAR, excess absolute risk; SIR, standardized incidence ratio.

treatment with chemotherapy (RR $7.01 \quad$ (95\% CI: 1.4-30.9) compared with survivors of other childhood cancer subtypes) (Guibout et al. 2005). This supports the idea that factors other than treatment exposures, like genetic determinants, may also contribute to secondary breast cancer development in Hodgkin lymphoma survivors. Although Maule and coworkers did not observe a significantly increased risk for secondary breast cancer in survivors of soft-tissue sarcoma, retinoblastoma, nephroblastoma, neuroblastoma, germ cell tumors and non-Hodgkin lymphoma, other studies did (Kenney et al. 2004, Guibout et al. 2005, Inskip \& Curtis 2007, Marees et al. 2008, Reulen et al. 2011, Lange et al. 2014, Little et al. 2014). The increased risk for secondary breast cancer in survivors of sarcoma might also be partly related to genetic factors. Data from the Childhood Cancer Survivor Study demonstrated an increased standardized incidence ratio for secondary breast cancer in sarcoma survivors not treated with chest irradiation (5.3 (95\% CI: 3.6-7.8)) (Henderson et al. 2015). In addition, a positive family history for sarcoma was associated with an increased secondary breast cancer risk (RR 5.3 (95\% CI: 1.3-21.5)) (Kenney et al. 2004). The increased risk for secondary breast cancer after retinoblastoma is observed in both heritable and nonheritable retinoblastoma survivors (Little et al. 2014), and seems to become apparent after $\geq 40$ years of follow-up since primary cancer diagnosis in heritable retinoblastoma survivors (Marees et al. 2008).

\section{Hormonal influences on secondary breast cancer risk}

In the general population, prolonged exposure to estrogens has been associated with an increased breast

Published by Bioscientifica Ltd. 
cancer risk (Clemons \& Goss 2001). Therefore, several studies investigated the risk-modifying effects of age at menarche, menopausal age, and age at first childbirth on secondary breast cancer in childhood- and young-adultonset cancer survivors (Travis et al. 2003, van Leeuwen et al. 2003, Kenney et al. 2004, Hill et al. 2005, De Bruin et al. 2009, Cooke et al. 2013). In contrast to observations in the general population, Cooke and coworkers demonstrated an increased risk for secondary breast cancer in Hodgkin lymphoma survivors experiencing a late menarche (OR 3.74 (95\% CI: 1.08-12.98) for age at menarche 17 vs 13 years) (Cooke et al. 2013). In addition, they observed a relationship between timing of chest irradiation in relation to menarche and secondary breast cancer risk. Secondary breast cancer risk was significantly increased in survivors treated with chest irradiation within 5 years of menarche; the smaller the interval between chest irradiation and menarche, the higher the risk for secondary breast cancer $(P<0.001$ for trend) (Cooke et al. 2013). Other studies could not demonstrate an association between age at menarche and secondary breast cancer risk (van Leeuwen et al. 2003, Kenney et al. 2004, Hill et al. 2005). In addition, no studies observed a risk-modifying effect of age at first childbirth on secondary breast cancer development in childhood- and young-adult-onset cancer survivors (van Leeuwen et al. 2003, Kenney et al. 2004, Hill et al. 2005). However, Hill and coworkers demonstrated a relationship between timing of childbirth in relation to Hodgkin lymphoma diagnosis and secondary breast cancer risk. Women not treated with alkylating agents or ovarian irradiation $\geq 5$ Gy who had childbirth within 5 years following Hodgkin lymphoma diagnosis demonstrated an increased secondary breast cancer risk compared with women who had childbirth at least 5 years after Hodgkin lymphoma diagnosis (OR 2.6 (95\% CI: 1.0-6.7)) (Hill et al. 2005). An increased risk for breast cancer shortly after childbirth has also been observed in the general population, and is thought to be related to gestational hormone exposure, immunosuppressive effects of pregnancy and postpartum breast involution (Lyons et al. 2009).

Several studies investigated the risk-modifying effects of age at menopause, premature ovarian insufficiency, alkylating agents and ovarian irradiation on radiationinduced breast cancer in survivors of childhood- and young-adult-onset cancer (Table 9) (Travis et al. 2003, van Leeuwen et al. 2003, Kenney et al. 2004, Hill et al. 2005, Taylor et al. 2007, De Bruin et al. 2009, Cooke et al. 2013, Schaapveld et al.2015). Studies in combined cohorts of childhood- and adult-onset Hodgkin lymphoma survivors consistently reported a protective effect of premature ovarian insufficiency on radiation-induced breast cancer risk (Travis et al. 2003, van Leeuwen et al. 2003, Hilletal.2005, De Bruinetal.2009, Cooke etal.2013). Risk for radiation-induced breast cancer seems to be lower in women experiencing less premenopausal years following Hodgkin lymphoma treatment (De Bruin et al. 2009, Cooke et al. 2013). Alkylating agent chemotherapy and ovarian irradiation are known to potentially induce premature ovarian insufficiency. Therefore, several studies investigated the risk-modifying effects of these therapies on radiation-induced breast cancer development. A protective effect of alkylating agent chemotherapy on radiation-induced breast cancer has been observed in combined cohorts of childhood- and adult-onset Hodgkin lymphoma survivors (Travis et al. 2003, 2005, van Leeuwen et al. 2003, De Bruin et al. 2009, Swerdlow et al. 2012, Schaapveld et al. 2015). In the studies by Travis and coworkers, and Van Leeuwen and coworkers, increasing cycles of alkylating agent chemotherapy and a high dose of procarbazine were significantly associated with a decreased risk for radiation-induced breast cancer (Travis et al. 2003, van Leeuwen et al. 2003). Note that no studies in cohorts of childhood cancer survivors solely could demonstrate a beneficial effect of alkylating agents on radiationinduced breast cancer risk. In addition, several studies in cohorts of childhood cancer survivors solely and childhood- and adult-onset cancer survivors combined observed a protective effect of ovarian irradiation on radiation-induced breast cancer (Fig. 2A) (Kenney et al. 2004, Constine et al. 2008, Inskip et al. 2009, Swerdlow et al. 2012, Moskowitz et al. 2014).

Although the aforementioned studies suggest protective effects of premature ovarian insufficiency and gonadotoxic therapies on radiation-induced breast cancer development, it is important to keep in mind that most of these studies were performed in combined cohorts of childhood- and adult-onset Hodgkin lymphoma survivors (Travis et al. 2003, 2005, van Leeuwen et al. 2003, Hill et al. 2005, De Bruin et al. 2009, Swerdlow et al. 2012, Cooke et al. 2013, Schaapveld et al. 2015). The beneficial effect of gonadotoxic treatment on radiation-induced breast cancer risk seems less pronounced in childhoodcompared with adult-onset cancer survivors. This is underscored by a recent study in survivors of Hodgkin lymphoma by Swerdlow and coworkers which observed a beneficial effect of gonadotoxic therapy on radiationinduced breast cancer risk only in women aged $\geq 20$ years at primary cancer treatment (Swerdlow et al. 2012).

Published by Bioscientifica Ltd 


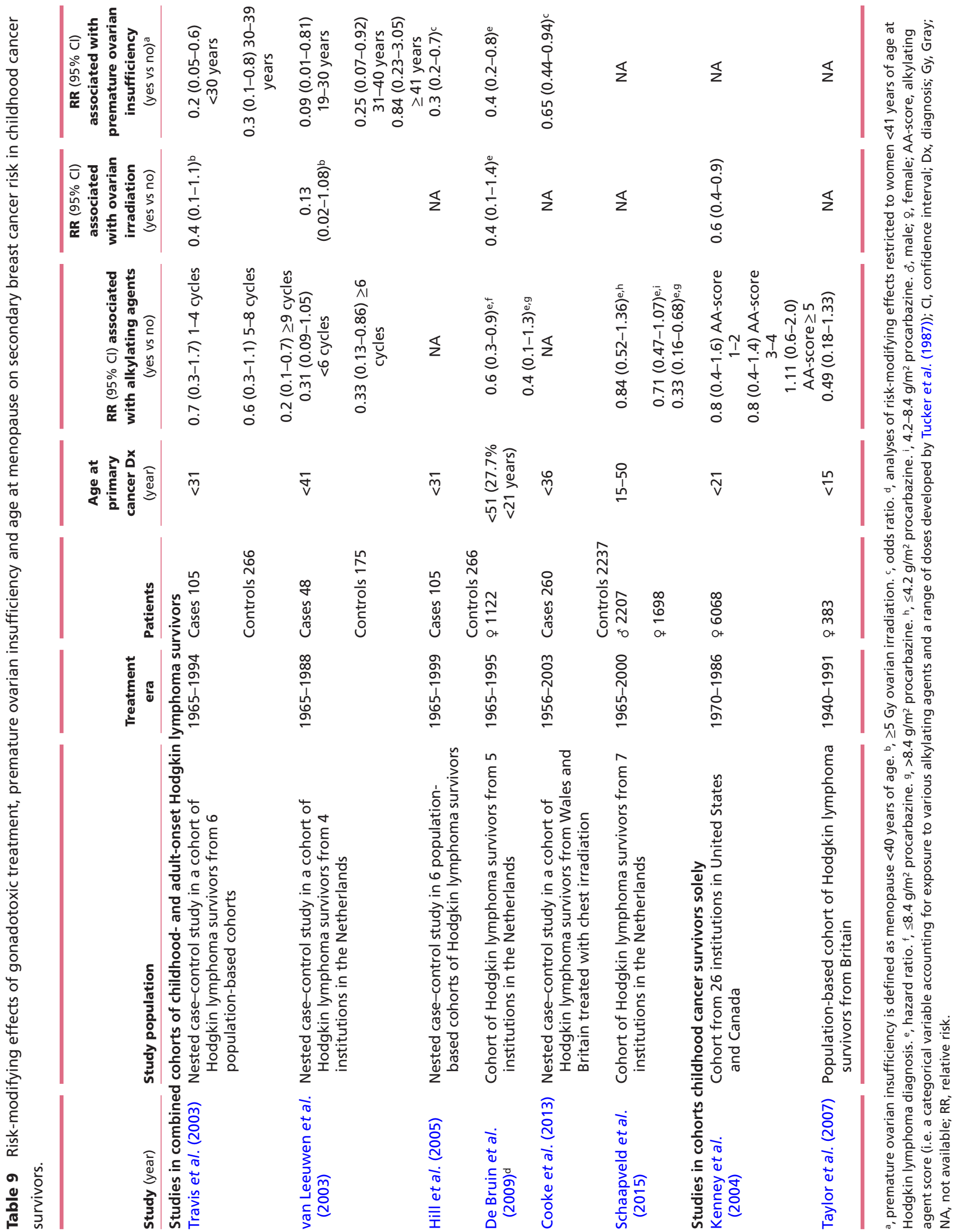


The less pronounced protective effect of gonadotoxic therapy in childhood- compared with adult-onset cancer survivors may be explained by a greater reserve of follicles in young women, which might be less likely to deplete following ovarian toxic treatment (Sklar 2005). Note that in a recent study in childhood cancer survivors not treated with chest irradiation, Henderson and coworkers could not demonstrate a protective effect of ovarian irradiation or alkylating agent chemotherapy on secondary breast cancer risk (Henderson et al. 2015). This indicates that gonadotoxic treatment only protects for radiationinduced breast cancer development.

Currently, there is no evidence of a harmful effect of estrogen-progestin replacement therapy on secondary breast cancer risk in premature ovarian-insufficient childhood cancer survivors (Travis et al. 2003, van Leeuwen et al. 2003, De Bruin et al. 2009). However, the number of women using estrogen-progestin replacement therapy in the available studies addressing this issue is too small to reliably evaluate this topic. Only recently, estrogen-progestin replacement therapy is prescribed commonly in premature ovarianinsufficient childhood cancer survivors (van Leeuwen et al. 2003). Since potential benefits of premature ovarian insufficiency on radiation-induced breast cancer risk have not been demonstrated in cohorts of solely childhood cancer survivors, and harms of estrogen-progestin replacement therapy on radiation-induced breast cancer risk in premature ovarian-insufficient childhood cancer survivors have not been described thus far, castration of female childhood cancer survivors at high risk for radiation-induced breast cancer should not be performed. This is underscored by the clearly demonstrated beneficial effects of estrogen-progestin replacement therapy on bone and cardiovascular health, as well as quality of life in women from the general population experiencing premature ovarian insufficiency (National Collaborating Centre for Women's and Children's Health 2015). The effect of oral contraceptives on secondary breast cancer risk in childhood cancer survivors has only been studied in combined cohorts of childhood- and adult-onset Hodgkin lymphoma survivors. No risk-modifying effects have been demonstrated (van Leeuwen et al. 2003, Hill et al. 2005, De Bruin et al. 2009).

\section{Thyroid cancer}

\section{Epidemiology and host-related risk factors}

Several recent large cohort studies in childhood cancer survivors observed significantly increased standardized incidence ratios for secondary thyroid carcinoma between 5.4 and 18.0 in comparison with the general population (Inskip \& Curtis 2007, Olsen et al. 2009, Taylor et al. 2009, Friedman et al. 2010). This represents a 30-year cumulative incidence of $1.4 \%$ (95\% CI: 1.1-1.6) since childhood cancer diagnosis (Friedman et al. 2010). The increased risk for secondary thyroid cancer in childhood cancer survivors involves predominantly differentiated thyroid carcinoma (i.e. papillary or follicular thyroid carcinoma) (Black et al. 1998, Taylor et al. 2009). Latency periods for the development of secondary thyroid carcinoma in childhood cancer survivors vary between 0.6 and 38 years (average 12.3 years) (Table 10) (Black et al. 1998, Bhatia et al. 2002, Acharya et al. 2003, Cohen et al. 2007, Constine et al. 2008, Diallo et al. 2009, Taylor et al. 2009, Veiga et al. 2012a, Danner-Koptik et al. 2013, Dorffel et al. 2015, Finke et al. 2015, Brignardello et al. 2016). A recent study by Veiga and coworkers included pooled data from the Childhood Cancer Survivor Study cohort (Bhatti et al. 2010), the Late Effects Study Group cohort (Tucker et al. 1991), the Nordic countries cohort (Svahn-Tapper et al. 2006) and a combined French and British cohort (de Vathaire et al. 1999). The study found that female gender (RR 2.0 (95\% CI: $1.5-2.8)$, younger age at primary cancer $(P<0.01$ for trend), longer follow-up since primary cancer $(P=0.01$ for trend), older attained survivor's age $(P<0.01$ for trend), and treatment with radiotherapy (RR 5.5 (95\% CI: 3.1-9.7)) were significantly associated with secondary thyroid carcinoma risk in childhood cancer survivors (Veiga et al. 2012b). A risk-modifying effect of gender and age at childhood cancer diagnosis has also been observed in other studies (Cohen et al. 2007, Constine et al. 2008), but not all (Somerville et al. 2002, Taylor et al. 2009). A recent study by De Vathaire et al. investigated the influence of smoking and overweight on secondary thyroid cancer risk in childhood cancer survivors, but could not demonstrate a significant effect (RR 0.75 (95\% CI: 0.32-1.6) for smoking; RR 1.4 (95\% CI: 0.7-2.80 for overweight)) (de Vathaire et al. 2015). Best and coworkers identified allelic variants in PRDM1 to predispose Hodgkin lymphoma survivors to radiation-induced thyroid cancer (Best et al. 2011). In addition, several studies identified allelic variants in TP53, ATM and FOXE1 to be associated with radiationinduced papillary thyroid carcinoma in survivors of the Chernobyl nuclear accident (Akulevich et al. 2009, Takahashi et al. 2010, Damiola et al. 2014). 


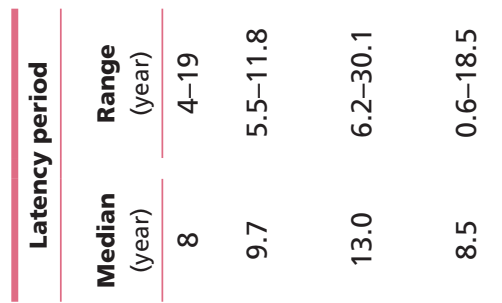

Ilyo a 8

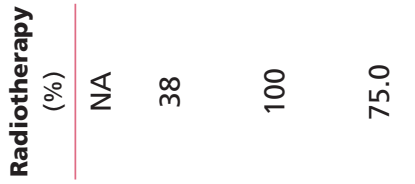

$\ln 1 \leq \leq \leq$

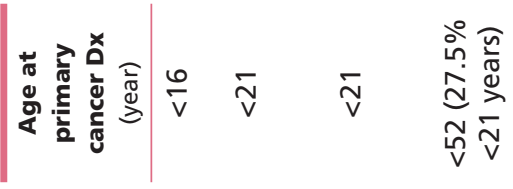

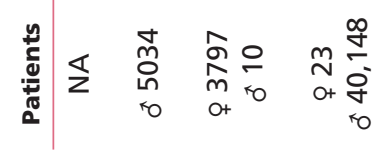

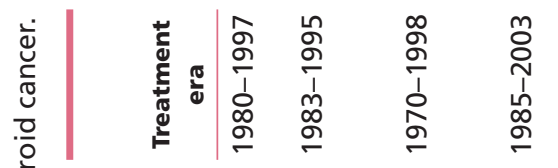

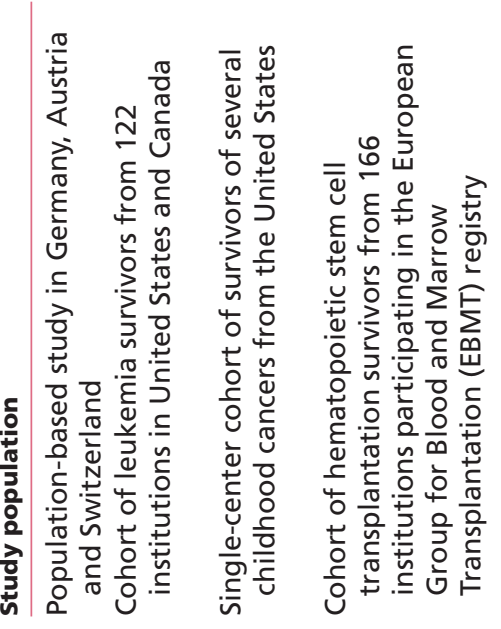

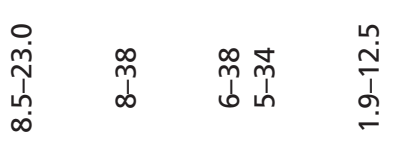

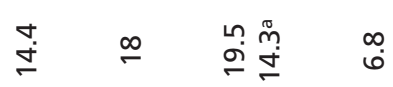

ㄷํㅇำ

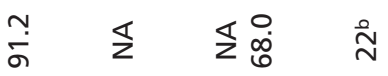

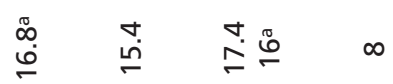

$\frac{\Re}{\bar{v}} \quad \stackrel{n}{\bar{v}} \overline{\mathrm{v}} \quad \bar{v}$

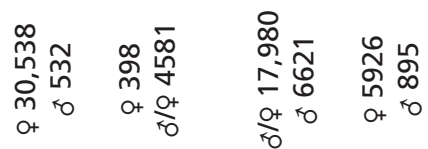

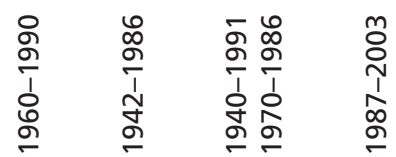

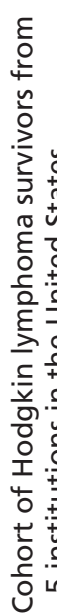
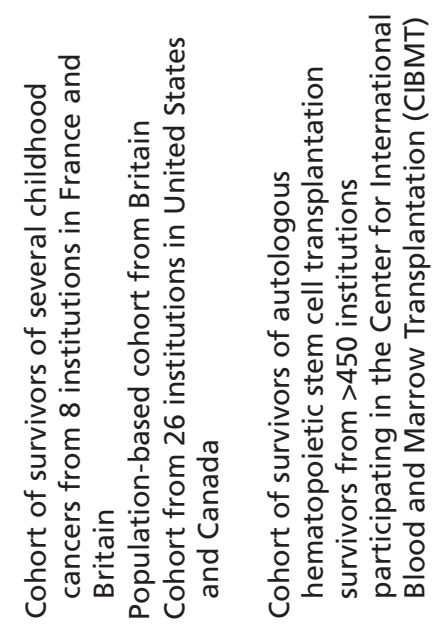

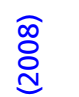

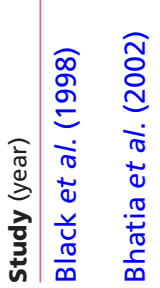

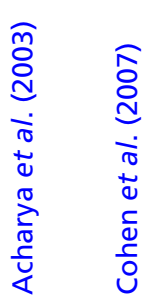

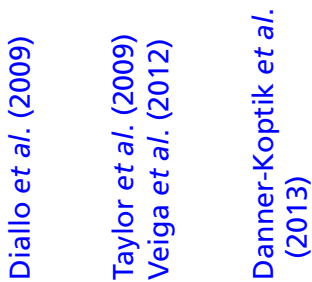

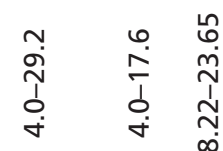

$\stackrel{\stackrel{m}{m}}{\stackrel{m}{\sigma}} \stackrel{\stackrel{\infty}{\circ}}{\stackrel{m}{m}}$

F

$\frac{\pi}{z} \stackrel{5}{2}$

$\stackrel{m}{\sim} \quad \mathbb{2} \stackrel{9}{\dot{m}}$

$\stackrel{\vartheta}{\mathrm{v}} \stackrel{\stackrel{n}{v}}{\stackrel{\infty}{v}}$

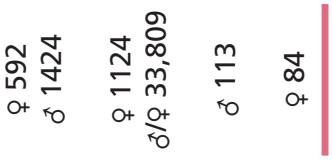

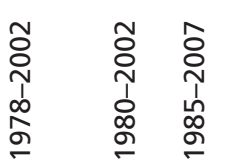

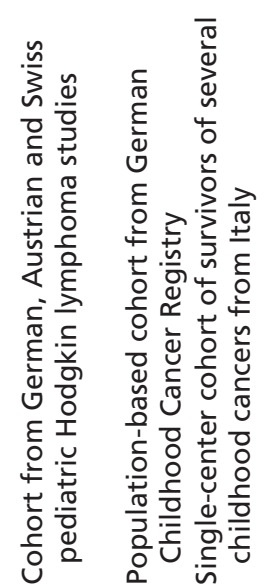

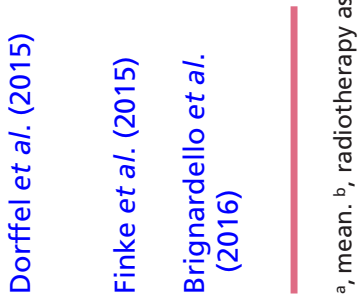




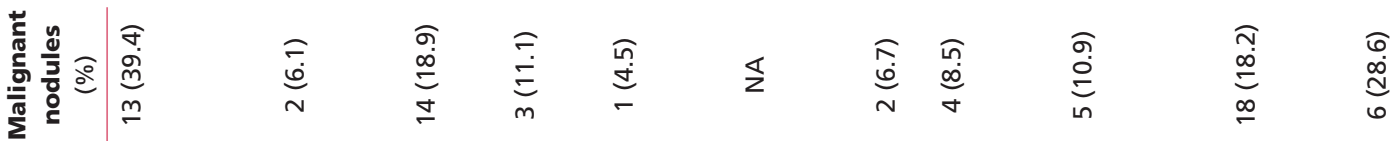

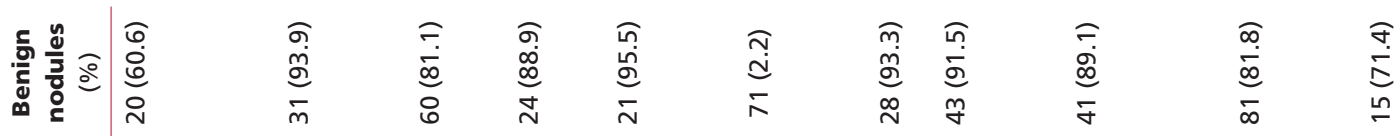
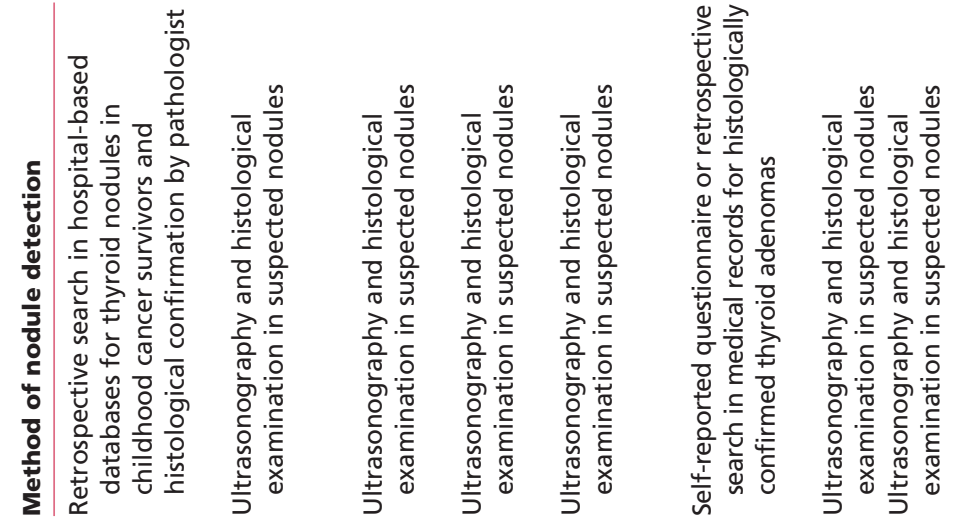

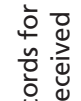

s.

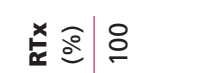

+

$\therefore$ ํํ

m

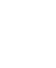

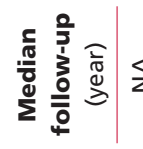

$\frac{10}{2}$

8

$\varangle \quad \stackrel{\circ}{\stackrel{\infty}{\infty}} \stackrel{\infty}{\sim} \stackrel{0}{\circ}$

$\stackrel{n}{\circ} \infty$

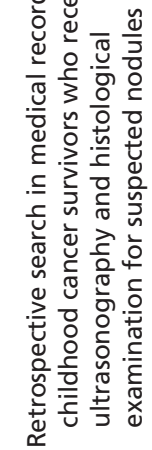

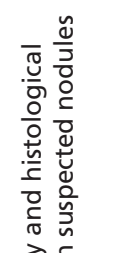

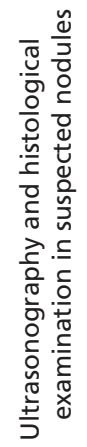

敫

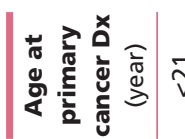

$\bar{v}$

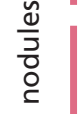

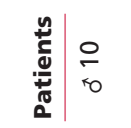

$\bar{v}$

$\bar{v} \quad \stackrel{\infty}{v} \quad \stackrel{\infty}{v} \quad \stackrel{\sim}{v}$

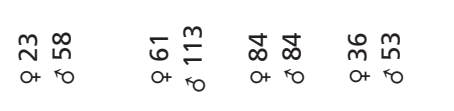

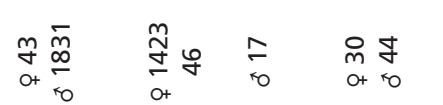

ind

$m$
$m$
$o+$

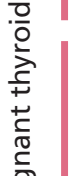

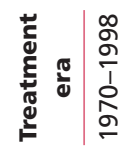

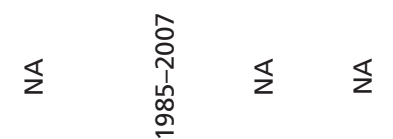

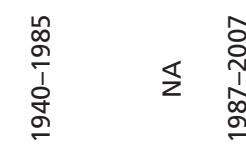

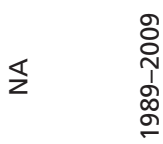

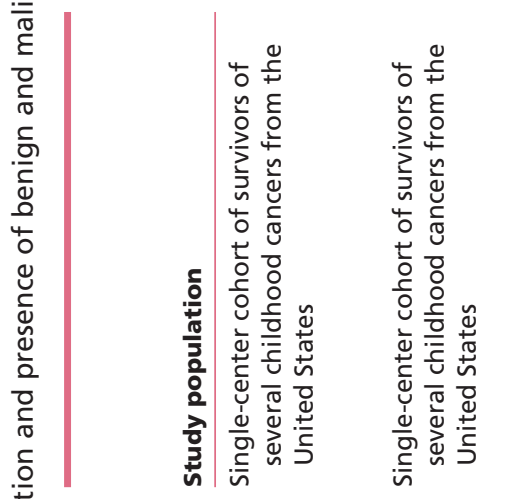

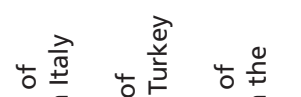

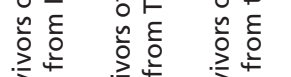

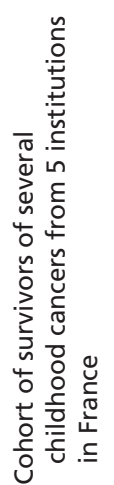

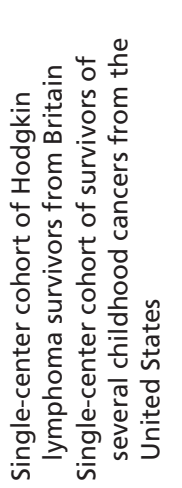

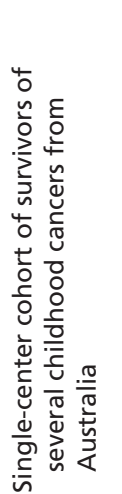

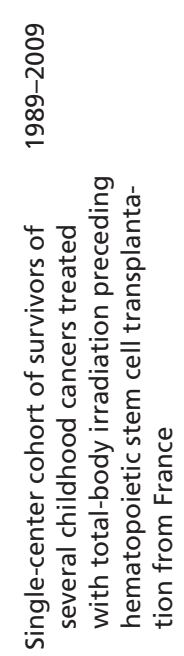

Oֶّ

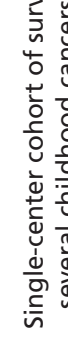

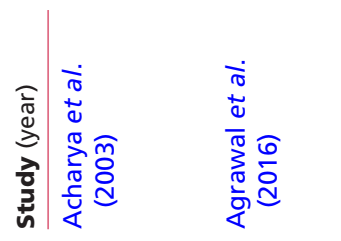

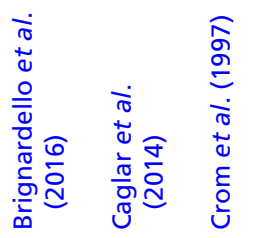

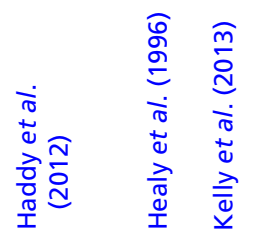

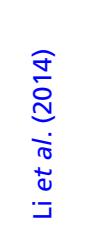

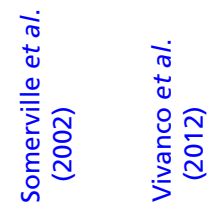




\section{Treatment-related risk factors for secondary thyroid carcinoma}

Radiotherapy involving the thyroid gland is the most important risk factor for secondary thyroid carcinoma in childhood cancer survivors, and seems to exert its effect via a sigmoidal dose-response relationship (Veiga et al. $2012 b$, de Vathaire et al. 2015). In the aforementioned pooled study by Veiga and coworkers, the dose-response relationship for thyroid carcinoma in survivors of pediatric cancer increased linearly until a radiation dose of approximately $10 \mathrm{~Gy}$, leveled off at a radiation dose of approximately 10-30 Gy, and declined again at a radiation dose $>30 \mathrm{~Gy}$. However, the risk for thyroid cancer still remained increased at a radiation dose $>50$ Gy (Veiga et al. $2012 b$ ). The downturn in the dose-response relationship for radiation-induced thyroid carcinoma is thought to be related to a cell-killing effect (Sigurdson et al. 2005). In Fig. 2B, the dose-response curve for secondary thyroid carcinoma following thyroid gland irradiation as reported by Bhatti and coworkers is shown (Bhatti et al. 2010). This study by Bhatti and coworkers is also included in the pooled analysis by Veiga and coworkers (Veiga et al. 2012b). Besides increasing the risk for differentiated thyroid carcinoma, radiotherapy involving the thyroid gland is also known to promote the occurrence of benign thyroid nodules in childhood cancer survivors (Table 11). Clinically, it may be difficult to distinguish malignant from benign thyroid nodules (Healy et al. 1996, Crom et al. 1997, Somerville et al. 2002, Acharya et al. 2003, Haddy et al. 2012, Vivanco et al. 2012, Kelly et al. 2013, Caglar et al. 2014, Li et al. 2014, Agrawal et al. 2016, Brignardello et al. 2016). Studies investigating radiation-related thyroid carcinoma risk after childhood cancer treatment have predominantly assessed older radiotherapeutic modalities. To our knowledge, observational studies on secondary thyroid carcinoma risk in childhood cancer survivors treated with modern radiotherapeutic techniques like conformal radiotherapy, intensity-modulated radiation therapy and proton-beam therapy have to be performed yet.

A few studies demonstrated an increased risk for secondary thyroid carcinoma in childhood cancer survivors attributable to chemotherapy (Veiga et al. $2012 a, b$, de Vathaire et al. 2015). Veiga and coworkers observed a 2.4-fold increased risk (95\% CI: 1.3-4.5) for secondary thyroid cancer in childhood cancer survivors treated with a combination of alkylating agents and $\leq 20$ Gy thyroid gland irradiation; the contribution of chemotherapy to secondary thyroid cancer risk declined with increasing thyroid gland irradiation dose $(P=0.03$ for trend) (Veiga et al. 2012a). In another study, Veiga and coworkers observed a 4.5 -fold increased risk (95\% CI: 1.4-17.8) for secondary thyroid carcinoma in childhood cancer survivors treated with anthracyclines without thyroid gland irradiation (Veiga et al. 2012b). A recent study by De Vathaire and coworkers demonstrated an increased secondary thyroid carcinoma risk in childhood cancer survivors treated with nitrosourea chemotherapy (RR 6.6 (95\% CI: 2.5-15.7)) (de Vathaire et al. 2015). Interestingly, in this study by De Vathaire and coworkers, childhood cancer treatment with splenectomy was also associated with an increased risk for secondary thyroid cancer (RR 2.3 (95\% CI: 1.3-4.0)), while pituitary irradiation $>10$ Gy decreased secondary thyroid carcinoma risk (RR 0.2 (95\% CI: 0.1-0.6)) (de Vathaire et al. 2015). In our institution, we could not demonstrate an increased risk for secondary thyroid cancer in survivors of childhood Hodgkin lymphoma treated with chemotherapy solely (van Beek et al. 2009, van Dorp et al. 2012).

Autologous and allogeneic hematopoietic stem cell transplantations are also associated with an increased secondary thyroid cancer risk (Socie et al. 2000, Cohen et al. 2007, Vivanco et al. 2012, Danner-Koptik et al. 2013). In a cohort of childhood- and adult-onset autologous and allogeneic hematopoietic stem cell transplantation survivors, Cohen and coworkers identified young age at transplantation (RR 24.61 (95\% CI: 4.45-136.25) for age $0-10$ vs $>20$ years), pretransplant conditioning with total-body irradiation (RR 3.44 (95\% CI: 1.41-8.37)), and chronic graft-versus-host disease (RR 2.94 (95\% CI: 1.21-7.15)) to increase the risk for secondary thyroid cancer (Cohen et al. 2007).

\section{Primary cancer diagnosis and secondary thyroid carcinoma risk}

Several childhood cancer subtypes have been associated with an increased secondary thyroid cancer risk (Table 12). Particularly, high risks for secondary thyroid carcinoma have been observed in survivors of neuroblastoma, Hodgkin lymphoma, non-Hodgkin lymphoma, brain tumors, and leukemia (Maule et al. 2007, 2008, 2011). In addition, De Vathaire and coworkers observed an increased risk for secondary thyroid carcinoma in survivors of gonadal tumors (SIR 16.0 (95\% CI: 4.0-41.4)) and soft-tissue sarcoma (SIR 8.2 (95\% CI 2.0-21.2)) (de Vathaire et al. 2015). Administered treatment modalities, like ${ }^{131} \mathrm{I}-\mathrm{MIBG}$ and radiotherapy involving the thyroid gland, may conceivably explain the increased risks for secondary thyroid cancer.

Published by Bioscientifica Ltd. 
Table 12 Risk for secondary thyroid cancer by childhood cancer subtype.

\begin{tabular}{l} 
Primary childhood cancer \\
diagnosis \\
\hline Leukemia \\
Hodgkin lymphoma \\
Non-Hodgkin lymphoma \\
Glioma \\
Embryonal central \\
nervous system tumors \\
Other central nervous \\
system tumors \\
Sympathetic nervous \\
system tumors \\
Retinoblastoma \\
Renal tumors \\
Bone sarcomas \\
Soft-tissue sarcomas \\
Epithelial tumors
\end{tabular}

\begin{tabular}{|c|c|}
\hline SIR $(95 \% \mathrm{CI})$ & $\begin{array}{c}\text { EAR per } 100,000 \\
\text { person-years }\end{array}$ \\
\hline $18.8(8.60-35.7)$ & 11.3 \\
\hline $52.5(24.0-99.6)$ & 62.7 \\
\hline $40.4(14.8-88.0)$ & 31.0 \\
\hline $6.8(1.9-18.0)$ & 7.2 \\
\hline $30(8.2-77)$ & 25 \\
\hline $7.7(0.2-43)$ & 8.8 \\
\hline $143.7(29.6-419.8)$ & 60.8 \\
\hline $5.3(0.1-29.6)$ & 3.8 \\
\hline $13.9(2.9-40.5)$ & 11.1 \\
\hline $10.8(1.3-38.9)$ & 14.3 \\
\hline $4.1(0.1-22.6)$ & 3.6 \\
\hline $3.3(0.1-18.4)$ & 3.4 \\
\hline
\end{tabular}

$\mathrm{Cl}$, confidence interval; EAR, excess absolute risk; SIR, standardized incidence ratio.

131I-MIBG (131-iodine metaiodobenzylguanidine) may be used to treat neuroblastoma, and involves administering a radioiodine-labeled guanidine derivate (Kayano \& Kinuya 2015). Approximately $2-5 \%$ of the administered 131I-MIBG enters the circulation as free radioiodine, and may affect thyroid functioning and induce thyroid nodules as well as secondary thyroid carcinoma (Clement et al. 2015).

\section{Limitations of currently available literature, and recommendations for future research}

The currently available literature on secondary endocrinerelated cancer risk in childhood cancer survivors has some limitations. Follow-up durations since childhood cancer are generally too short to assess the risk for secondary malignant neoplasms in aging childhood cancer survivors. Average follow-up durations since childhood cancer vary between 6.3 and 27.3 years in studies assessing secondary breast cancer risk (Hancock et al. 1993, Metayer et al. 2000, Ng et al. 2002, Bhatia et al. 2003, Gold et al. 2003, Guibout et al. 2005, Inskip \& Curtis 2007, Constine et al. 2008, Friedman et al. 2008, Marees et al. 2008, Alm El-Din et al. 2009, De Bruin et al. 2009, Maule et al. 2011, Reulen et al. 2011, Cooke et al. 2013, Danner-Koptik et al. 2013, Little et al. 2014, Dorffel et al. 2015, Moskowitz et al. 2015, Schaapveld et al. 2015), and 5.1-27 years in studies investigating secondary thyroid carcinoma risk (Crom et al. 1997, Bhatia et al. 2002, Cohen et al. 2007, Inskip \& Curtis 2007, Constine et al. 2008, Taylor et al. 2009, van Beek et al. 2009, Friedman et al. 2010, Maule et al. 2011, Vivanco et al. 2012, Danner-Koptik et al. 2013, Caglar et al. 2014, Li et al. 2014, Clement et al. 2015, de Vathaire et al. 2015, Dorffel et al. 2015, Brignardello et al. 2016). Specific subtypes of secondary malignant neoplasms and potential risk-modifying factors yet unknown may become apparent at an advanced survivor's age. Therefore, it is important to prospectively evaluate the growing cohort of aging childhood cancer survivors.

Furthermore, a large amount of the evidence on secondary breast cancer risk in childhood cancer survivors (Kenney et al. 2004, Marees et al. 2008, Inskip et al. 2009, Friedman et al. 2010, O'Brien et al. 2010, Moskowitz et al. 2014, 2015, Dorffel et al. 2015, Henderson et al. 2015) and, to a lesser extent, on secondary thyroid cancer risk in childhood cancer survivors (Sigurdson et al. 2005, Bhatti et al. 2010, Friedman et al. 2010, Veiga et al. 2012a, de Vathaire et al. 2015, Dorffel et al. 2015) has been derived from retrospective cohort studies using self-reported data to ascertain secondary malignant neoplasms, which may predispose to selection bias. Another source for selection bias may be the nature of the cohort. This is illustrated by Ness et al., who observed an overestimation of the prevalence of long-term adverse health conditions by $9.3 \% \quad(95 \%$ CI: 7.0-11.6) in childhood cancer survivors ascertained in a hospital- compared with a population-based setting (Ness et al. 2009). Future studies on secondary endocrine-related malignancies after childhood cancer could be prospective, based on national registries, and use objective methods to collect data on secondary malignant neoplasms.

Although several studies reported a protective effect of gonadotoxic therapies and premature ovarian insufficiency on radiation-induced breast cancer (Travis et al. 2003, 2005, van Leeuwen et al. 2003, Kenney et al. 2004, Hill et al. 2005, Constine et al. 2008, De Bruin et al. 2009, Inskip et al. 2009, Cooke et al. 2013, Moskowitz et al. 2014, Schaapveld et al. 2015), it is important to consider that most of these studies were performed in combined cohorts of childhood- and adult-onset Hodgkin lymphoma survivors (Travis et al. 2003, 2005, van Leeuwen et al. 2003, Hill et al. 2005, De Bruin et al. 2009, Cooke et al. 2013, Schaapveld et al. 2015). Since the beneficial effects of gonadotoxic treatments on radiationinduced breast cancer risk seem less pronounced in childhood- compared with adult-onset cancer survivors (Swerdlow et al. 2012), and no studies assessed the riskmodifying effect of a diagnosis of premature ovarian insufficiency on radiation-induced breast cancer in

Published by Bioscientifica Ltd 
childhood cancer survivors solely, more studies should be performed. Future studies may also address the potential harms and benefits of estrogen-progestin replacement therapy on radiation-induced breast cancer risk in women experiencing childhood cancer treatmentrelated premature ovarian insufficiency.

Studies on secondary malignant neoplasms after childhood cancer concern predominantly survivors treated with old-fashioned treatment regimens. Although childhood cancer therapy has changed considerably over the past five decades (Kumar 2012, Hudson et al. 2014), results described in this review are still highly valuable for those individuals treated in earlier treatment eras. Since the effects of modern radiotherapeutic techniques like conformal radiotherapy, intensity-modulated radiation therapy and proton-beam therapy on secondary endocrine-related cancer risk remain unknown, future studies should address the potential risks and benefits associated with these contemporary radiotherapeutic modalities. Risks for radiation-induced malignant neoplasms may be greater in small compared with large children due to a more significant contribution of scatter radiation (Hall 2006). Currently, no studies on secondary endocrine-related malignancies after childhood cancer accounted for this issue. Future studies may investigate radiation-induced cancer risks by dosimetry according to body size at cancer treatment.

Finally, there is a lack of studies specifically investigating the influence of environmental and lifestyle factors on secondary endocrine-related cancer risk in childhood cancer survivors. Future studies should address these potentially risk-modifying factors.

\section{Conclusion}

Secondary malignant neoplasm development in childhood cancer survivors depends on host factors, primary cancer diagnosis, and types and timing of primary cancer treatment. In addition, environmental factors and lifestyle factors may play a contributing role. Radiotherapy is the most important risk factor for secondary breast and thyroid cancer in childhood cancer survivors. Premature ovarian insufficiency may protect against radiation-induced breast cancer. Although evidence is weak, there seems to be no harmful effect of estrogen-progestin replacement therapy on radiation-induced breast cancer risk in premature ovarian-insufficient childhood cancer survivors. Childhood cancer survivors at risk for secondary endocrine-related malignancies should be regularly screened in a risk-based fashion, preferably by endocrinologists in close collaboration with physicians experienced in long-term complications of childhood cancer treatment.

Declaration of interest

The authors declare that there is no conflict of interest that could be perceived as prejudicing the impartiality of this review.

\section{Funding}

This research did not receive any specific grant from any funding agency in the public, commercial or not-for-profit sector.

\section{References}

Acharya S, Sarafoglou K, LaQuaglia M, Lindsley S, Gerald W, Wollner N, Tan C \& Sklar C 2003 Thyroid neoplasms after therapeutic radiation for malignancies during childhood or adolescence. Cancer $\mathbf{9 7}$ 2397-2403. (doi:10.1002/cncr.11362)

Agrawal C, Guthrie L, Sturm MS, Stanek J, Martin L, Henwood-Finley M, Aldrink JH, Olshefski R \& O'Brien SH 2016 Comparison of thyroid nodule prevalence by ultrasound in childhood cancer survivors with and without thyroid radiation exposure. Journal of Pediatric Hematology Oncology 38 43-48. (doi:10.1097/ MPH.0000000000000473)

Akulevich NM, Saenko VA, Rogounovitch TI, Drozd VM, Lushnikov EF, Ivanov VK, Mitsutake N, Kominami R \& Yamashita S 2009 Polymorphisms of DNA damage response genes in radiation-related and sporadic papillary thyroid carcinoma. Endocrine-Related Cancer 16 491-503. (doi:10.1677/ERC-08-0336)

Alm El-Din MA, Hughes KS, Finkelstein DM, Betts KA, Yock TI, Tarbell NJ, Aisenberg AC \& Taghian AG 2009 Breast cancer after treatment of Hodgkin's lymphoma: risk factors that really matter. International Journal of Radiation Oncology, Biology, Physics 73 69-74. (doi:10.1016/j.ijrobp.2008.03.066)

Armstrong GT, Liu Q, Yasui Y, Neglia JP, Leisenring W, Robison LL \& Mertens AC 2009 Late mortality among 5-year survivors of childhood cancer: a summary from the Childhood Cancer Survivor Study. Journal of Clinical Oncology 27 2328-2338. (doi:10.1200/ JCO.2008.21.1425)

Armstrong GT, Stovall M \& Robison LL 2010 Long-term effects of radiation exposure among adult survivors of childhood cancer: results from the childhood cancer survivor study. Radiation Research 174 840-850. (doi:10.1667/RR1903.1)

Armstrong GT, Chen Y, Yasui Y, Leisenring W, Gibson TM, Mertens AC, Stovall M, Oeffinger KC, Bhatia S, Krull KR, et al. 2016 Reduction in late mortality among 5-year survivors of childhood cancer. New England Journal of Medicine 374 833-842. (doi:10.1056/ NEJMoa1510795)

Barcellos-Hoff MH 2013 New biological insights on the link between radiation exposure and breast cancer risk. Journal of Mammary Gland Biology and Neoplasia 18 3-13. (doi:10.1007/s10911-013-9272-x)

Berrington de Gonzalez A, Gilbert E, Curtis R, Inskip P, Kleinerman R, Morton L, Rajaraman P \& Little MP 2013 Second solid cancers after radiation therapy: a systematic review of the epidemiologic studies of the radiation dose-response relationship. International Journal of Radiation Oncology, Biology, Physics 86 224-233.

Best T, Li D, Skol AD, Kirchhoff T, Jackson SA, Yasui Y, Bhatia S, Strong LC, Domchek SM, Nathanson KL, et al. 2011 Variants at 6q21 implicate PRDM1 in the etiology of therapy-induced second malignancies after Hodgkin's lymphoma. Nature Medicine 17 941-943. (doi:10.1038/nm.2407) 
Bhatia S, Sather HN, Pabustan OB, Trigg ME, Gaynon PS \& Robison LL 2002 Low incidence of second neoplasms among children diagnosed with acute lymphoblastic leukemia after 1983. Blood 99 4257-4264. (doi:10.1182/blood.V99.12.4257)

Bhatia S, Yasui Y, Robison LL, Birch JM, Bogue MK, Diller L, DeLaat C, Fossati-Bellani F, Morgan E, Oberlin O, et al. 2003 High risk of subsequent neoplasms continues with extended follow-up of childhood Hodgkin's disease: report from the Late Effects Study Group. Journal of Clinical Oncology 21 4386-4394.

Bhatti P, Veiga LH, Ronckers CM, Sigurdson AJ, Stovall M, Smith SA, Weathers R, Leisenring W, Mertens AC, Hammond S, et al. 2010 Risk of second primary thyroid cancer after radiotherapy for a childhood cancer in a large cohort study: an update from the childhood cancer survivor study. Radiation Research 174 741-752. (doi:10.1667/RR2240.1)

Black P, Straaten A \& Gutjahr P 1998 Secondary thyroid carcinoma after treatment for childhood cancer. Medical and Pediatric Oncology 31 91-95. (doi:10.1002/(sici)1096-911x(199808)31:2<91::aid-mpo8>3.0.co;2-u)

Brignardello E, Felicetti F, Castiglione A, Gallo M, Maletta F, Isolato G, Biasin E, Fagioli F, Corrias A \& Palestini N 2016 Ultrasound surveillance for radiation-induced thyroid carcinoma in adult survivors of childhood cancer. European Journal of Cancer 55 74-80. (doi:10.1016/j.ejca.2015.12.006)

Broeks A, Russell NS, Floore AN, Urbanus JH, Dahler EC, van't Veer MB, Hagenbeek A, Noordijk EM, Crommelin MA, van Leeuwen FE, et al. 2000 Increased risk of breast cancer following irradiation for Hodgkin's disease is not a result of ATM germline mutations. International Journal Radiation Biology 76 693-698.

Caglar AA, Oguz A, Pinarli FG, Karadeniz C, Okur A, Bideci A, Kocak U \& Bora H 2014 Thyroid abnormalities in survivors of childhood cancer. Journal of Clinical Research in Pediatric Endocrinology 6 144-151.

Carpenter DO \& Bushkin-Bedient S 2013 Exposure to chemicals and radiation during childhood and risk for cancer later in life. Journal of Adolescent Health 52 S21-29.

Choi DK, Helenowski I \& Hijiya N 2014 Secondary malignancies in pediatric cancer survivors: perspectives and review of the literature. International Journal of Cancer 135 1764-1773. (doi:10.1002/ijc.28991)

Clement SC, van Eck-Smit BL, van Trotsenburg AS, Kremer LC, Tytgat GA \& van Santen HM 2013 Long-term follow-up of the thyroid gland after treatment with 131I-Metaiodobenzylguanidine in children with neuroblastoma: importance of continuous surveillance. Pediatric Blood \& Cancer 60 1833-1838.

Clement SC, van Rijn RR, van Eck-Smit BL, van Trotsenburg AS, Caron HN, Tytgat GA \& van Santen HM 2015 Long-term efficacy of current thyroid prophylaxis and future perspectives on thyroid protection during 131I-metaiodobenzylguanidine treatment in children with neuroblastoma. European Journal of Nuclear Medicine and Molecular Imaging 42 706-715. (doi:10.1007/s00259-014-2967-4)

Clemons M \& Goss P 2001 Estrogen and the risk of breast cancer. New England Journal of Medicine 344 276-285. (doi:10.1056/ NEJM200101253440407)

Cohen A, Rovelli A, Merlo DF, van Lint MT, Lanino E, Bresters D, Ceppi M, Bocchini V, Tichelli A \& Socie G 2007 Risk for secondary thyroid carcinoma after hematopoietic stem-cell transplantation: an EBMT Late Effects Working Party Study. Journal of Clinical Oncology 25 2449-2454. (doi:10.1200/JCO.2006.08.9276)

Constine LS, Tarbell N, Hudson MM, Schwartz C, Fisher SG, Muhs AG, Basu SK, Kun LE, Ng A, Mauch P, et al. 2008 Subsequent malignancies in children treated for Hodgkin's disease: associations with gender and radiation dose. International Journal of Radiation Oncology, Biology, Physics 72 24-33. (doi:10.1016/j.ijrobp.2008.04.067)

Cooke R, Jones ME, Cunningham D, Falk SJ, Gilson D, Hancock BW, Harris SJ, Horwich A, Hoskin PJ, Illidge T, et al. 2013 Breast cancer risk following Hodgkin lymphoma radiotherapy in relation to menstrual and reproductive factors. British Journal of Cancer $\mathbf{1 0 8}$ 2399-2406. (doi:10.1038/bjc.2013.219)
Crom DB, Kaste SC, Tubergen DG, Greenwald CA, Sharp GB \& Hudson MM 1997 Ultrasonography for thyroid screening after head and neck irradiation in childhood cancer survivors. Medical and Pediatric Oncology 28 15-21. (doi:10.1002/(sici)1096911x(199701)28:1<15::aid-mpo4>3.0.co;2-w)

Damiola F, Byrnes G, Moissonnier M, Pertesi M, Deltour I, Fillon A, Le Calvez-Kelm F, Tenet V, McKay-Chopin S, McKay JD, et al. 2014 Contribution of ATM and FOXE1 (TTF2) to risk of papillary thyroid carcinoma in Belarusian children exposed to radiation. International Journal of Cancer 134 1659-1668. (doi:10.1002/ijc.28483)

Danner-Koptik KE, Majhail NS, Brazauskas R, Wang Z, Buchbinder D, Cahn JY, Dilley KJ, Frangoul HA, Gross TG, Hale GA, et al. 2013 Second malignancies after autologous hematopoietic cell transplantation in children. Bone Marrow Transplantation 48 363-368. (doi:10.1038/bmt.2012.166)

De Bruin ML, Sparidans J, van't Veer MB, Noordijk EM, Louwman MW, Zijlstra JM, van den Berg H, Russell NS, Broeks A, Baaijens MH, et al. 2009 Breast cancer risk in female survivors of Hodgkin's lymphoma: lower risk after smaller radiation volumes. Journal of Clinical Oncology 27 4239-4246.

de Vathaire F, Hardiman C, Shamsaldin A, Campbell S, Grimaud E, Hawkins M, Raquin M, Oberlin O, Diallo I, Zucker JM, et al. 1999 Thyroid carcinomas after irradiation for a first cancer during childhood. Archives of Internal Medicine 159 2713-2719. (doi:10.1001/archinte.159.22.2713)

de Vathaire F, Haddy N, Allodji RS, Hawkins M, Guibout C, El-Fayech C, Teinturier C, Oberlin O, Pacquement H, Diop F, et al. 2015 Thyroid radiation dose and other risk factors of thyroid carcinoma following childhood cancer. Journal of Clinical Endocrinology and Metabolism 100 4282-4290. (doi:10.1210/jc.2015-1690)

Diallo I, Haddy N, Adjadj E, Samand A, Quiniou E, Chavaudra J, Alziar I, Perret N, Guerin S, Lefkopoulos D, et al. 2009 Frequency distribution of second solid cancer locations in relation to the irradiated volume among 115 patients treated for childhood cancer. International Journal of Radiation Oncology, Biology, Physics 74 876883. (doi:10.1016/j.ijrobp.2009.01.040)

Dorffel W, Riepenhausenl M, Luders H, Bramswig J \& Schellong G 2015 Secondary malignancies following treatment for Hodgkin's lymphoma in childhood and adolescence. Deutsches Arzteblatt International 112 320-327.

Finke I, Scholz-Kreisel P, Hennewig U, Blettner M \& Spix C 2015 Radiotherapy and subsequent thyroid cancer in German childhood cancer survivors: a nested case-control study. Radiation Oncology 10219.

Foulkes WD, Priest JR \& Duchaine TF 2014 DICER1: mutations, microRNAs and mechanisms. Nature Reviews. Cancer 14 662-672. (doi:10.1038/nrc3802)

Frank C, Fallah M, Sundquist J, Hemminki A \& Hemminki K 2015 Population landscape of familial cancer. Scientific Reports 512891. (doi:10.1038/srep12891)

Friedman DL, Kadan-Lottick NS, Whitton J, Mertens AC, Yasui Y, Liu Y, Meadows AT, Robison LL \& Strong LC 2005 Increased risk of cancer among siblings of long-term childhood cancer survivors: a report from the childhood cancer survivor study. Cancer Epidemiology, Biomarkers \& Prevention 14 1922-1927.

Friedman DL, Rovo A, Leisenring W, Locasciulli A, Flowers ME, Tichelli A, Sanders JE, Deeg HJ, Socie G, Fhcrc, et al. 2008 Increased risk of breast cancer among survivors of allogeneic hematopoietic cell transplantation: a report from the FHCRC and the EBMT-Late Effect Working Party. Blood 111 939-944.

Friedman DL, Whitton J, Leisenring W, Mertens AC, Hammond S, Stovall M, Donaldson SS, Meadows AT, Robison LL \& Neglia JP 2010 Subsequent neoplasms in 5-year survivors of childhood cancer: the Childhood Cancer Survivor Study. Journal of the National Cancer Institute 102 1083-1095. (doi:10.1093/jnci/djq238)

Garwicz S, Anderson H, Olsen JH, Winther JF, Sankila R, Langmark F, Tryggvadottir L, Moller TR, Association of the Nordic Cancer 
Registries \& Nordic Society for Pediatric Hematology Oncology 2012 Late and very late mortality in 5-year survivors of childhood cancer: changing pattern over four decades - experience from the Nordic countries. International Journal of Cancer 131 1659-1666.

Gatta G, Botta L, Rossi S, Aareleid T, Bielska-Lasota M, Clavel J, Dimitrova N, Jakab Z, Kaatsch P, Lacour B, et al. 2014 Childhood cancer survival in Europe 1999-2007: results of EUROCARE-5 - a population-based study. Lancet Oncology 15 35-47. (doi:10.1016/ S1470-2045(13)70548-5)

Geenen MM, Cardous-Ubbink MC, Kremer LC, van den Bos C, van der Pal HJ, Heinen RC, Jaspers MW, Koning CC, Oldenburger F, Langeveld NE, et al. 2007 Medical assessment of adverse health outcomes in long-term survivors of childhood cancer. JAMA 297 2705-2715. (doi:10.1001/jama.297.24.2705)

Gold DG, Neglia JP \& Dusenbery KE 2003 Second neoplasms after megavoltage radiation for pediatric tumors. Cancer 97 2588-2596. (doi:10.1002/cncr.11356)

Guibout C, Adjadj E, Rubino C, Shamsaldin A, Grimaud E, Hawkins M, Mathieu MC, Oberlin O, Zucker JM, Panis X, et al. 2005 Malignant breast tumors after radiotherapy for a first cancer during childhood. Journal of Clinical Oncology 23 197-204. (doi:10.1200/ JCO.2005.06.225)

Haddy N, El-Fayech C, Guibout C, Adjadj E, Thomas-Teinturier C, Oberlin O, Veres C, Pacquement H, Jackson A, Munzer M, et al. 2012 Thyroid adenomas after solid cancer in childhood. International Journal of Radiation Oncology, Biology, Physics 84 e209-e215.

Hall EJ 2006 Intensity-modulated radiation therapy, protons, and the risk of second cancers. International Journal of Radiation Oncology, Biology, Physics 65 1-7. (doi:10.1016/j.ijrobp.2006.01.027)

Hancock SL, Tucker MA \& Hoppe RT 1993 Breast cancer after treatment of Hodgkin's disease. Journal of the National Cancer Institute 85 25-31. (doi:10.1093/jnci/85.1.25)

Hardefeldt PJ, Eslick GD \& Edirimanne S 2012 Benign thyroid disease is associated with breast cancer: a meta-analysis. Breast Cancer Research and Treatment 133 1169-1177. (doi:10.1007/s10549-012-2019-3)

Healy JC, Shafford EA, Reznek RH, Webb JA, Thomas JM, Bomanji JB \& Kingston JE 1996 Sonographic abnormalities of the thyroid gland following radiotherapy in survivors of childhood Hodgkin's disease. British Journal of Radiology 69 617-623. (doi:10.1259/0007-1285-69823-617)

Henderson TO, Amsterdam A, Bhatia S, Hudson MM, Meadows AT, Neglia JP, Diller LR, Constine LS, Smith RA, Mahoney MC, et al. 2010 Systematic review: surveillance for breast cancer in women treated with chest radiation for childhood, adolescent, or young adult cancer. Annals of Internal Medicine 152 444-455; W144-W454.

Henderson TO, Moskowitz CS, Chou JF, Bradbury AR, Neglia JP, Dang CT, Onel K, Novetsky Friedman D, Bhatia S, Strong LC, et al. 2015 Breast cancer risk in childhood cancer survivors without a history of chest radiotherapy: a report from the Childhood Cancer Survivor Study. Journal of Clinical Oncology 34 910-918.

Hewitt M, Weiner SL \& Simone JV 2003 In Childhood Cancer Survivorship: Improving Care and Quality of Life. Washington, DC, USA: National Academies Press.

Hill DA, Gilbert E, Dores GM, Gospodarowicz M, van Leeuwen FE, Holowaty E, Glimelius B, Andersson M, Wiklund T, Lynch CF, et al. 2005 Breast cancer risk following radiotherapy for Hodgkin lymphoma: modification by other risk factors. Blood 106 3358-3365. (doi:10.1182/blood-2005-04-1535)

Hjorth L, Haupt R, Skinner R, Grabow D, Byrne J, Karner S, Levitt G, Michel G, van der Pal H, Bardi E, et al. 2015 Survivorship after childhood cancer: PanCare: a European Network to promote optimal long-term care. European Journal of Cancer 51 1203-1211. (doi:10.1016/j.ejca.2015.04.002)

Howlader N, Noone AM, Krapcho M, Garshell J, Miller D, Altekruse SF, Kosary CL, Yu M, Ruhl J, Tatalovich Z, et al. 2015 SEER Cancer Statistics Review, 1975-2012, National Cancer Institute. Bethesda,
MD, USA, http://seer.cancer.gov/csr/1975_2012/, based on November 2014 SEER data submission, posted to the SEER web site, April 2015.

Hudson MM, Ness KK, Gurney JG, Mulrooney DA, Chemaitilly W, Krull KR, Green DM, Armstrong GT, Nottage KA, Jones KE, et al. 2013 Clinical ascertainment of health outcomes among adults treated for childhood cancer. JAMA 309 2371-2381. (doi:10.1001/ jama.2013.6296)

Hudson MM, Link MP \& Simone JV 2014 Milestones in the curability of pediatric cancers. Journal of Clinical Oncology 32 2391-2397. (doi:10.1200/JCO.2014.55.6571)

Inskip PD \& Curtis RE 2007 New malignancies following childhood cancer in the United States, 1973-2002. International Journal of Cancer $1212233-2240$.

Inskip PD, Robison LL, Stovall M, Smith SA, Hammond S, Mertens AC, Whitton JA, Diller L, Kenney L, Donaldson SS, et al. 2009 Radiation dose and breast cancer risk in the childhood cancer survivor study. Journal of Clinical Oncology 27 3901-3907. (doi:10.1200/ JCO.2008.20.7738)

Kamiya K, Ozasa K, Akiba S, Niwa O, Kodama K, Takamura N, Zaharieva EK, Kimura Y \& Wakeford R 2015 Long-term effects of radiation exposure on health. Lancet 386 469-478. (doi:10.1016/ S0140-6736(15)61167-9)

Kayano D \& Kinuya S 2015 Iodine-131 metaiodobenzylguanidine therapy for neuroblastoma: reports so far and future perspective. Scientific World Journal 2015189135.

Kelly C, Rivard L, Salvi S, Hayani A, Hopkins W, O’Brien S, Martin L \& Canner J 2013 Surveillance following head, neck, and chest radiotherapy: thyroid ultrasound monitoring for secondary thyroid malignancy. Pediatric Blood \& Cancer 60 140-142.

Kenney LB, Yasui Y, Inskip PD, Hammond S, Neglia JP, Mertens AC, Meadows AT, Friedman D, Robison LL \& Diller L 2004 Breast cancer after childhood cancer: a report from the Childhood Cancer Survivor Study. Annals of Internal Medicine 141 590-597.

Kumar S 2012 Second malignant neoplasms following radiotherapy. International Journal of Environmental Research and Public Health 9 4744-4759. (doi:10.3390/ijerph9124744)

Lange JM, Takashima JR, Peterson SM, Kalapurakal JA, Green DM \& Breslow NE 2014 Breast cancer in female survivors of Wilms tumor: a report from the national Wilms tumor late effects study. Cancer 120 3722-3730.

Latz D, Alfrink M, Nassar N \& Beyerle C 2004 Breast cancer in a male patient after treatment of acute lymphoblastic leukemia including total body irradiation and bone marrow transplantation. Onkologie 27 477-479.

Li Z, Franklin J, Zelcer S, Sexton T \& Husein M 2014 Ultrasound surveillance for thyroid malignancies in survivors of childhood cancer following radiotherapy: a single institutional experience. Thyroid 24 1796-1805. (doi:10.1089/thy.2014.0132)

Little MP, Schaeffer ML, Reulen RC, Abramson DH, Stovall M, Weathers R, de Vathaire F, Diallo I, Seddon JM, Hawkins MM, et al. 2014 Breast cancer risk after radiotherapy for heritable and nonheritable retinoblastoma: a US-UK study. British Journal of Cancer 110 2623-2632. (doi:10.1038/bjc.2014.193)

Lowe T, Luu T, Shen J, Bhatia S, Shibata S, Stein A \& Somlo G 2008 Male breast cancer 15 years after allogeneic hematopoietic cell transplantation including total body irradiation for recurrent acute lymphoblastic leukemia. Onkologie 31 266-269. (doi:10.1159/000121395)

Lyons TR, Schedin PJ \& Borges VF 2009 Pregnancy and breast cancer: when they collide. Journal of Mammary Gland Biology and Neoplasia 14 87-98. (doi:10.1007/s10911-009-9119-7)

Ma YP, van Leeuwen FE, Cooke R, Broeks A, Enciso-Mora V, Olver B, Lloyd A, Broderick P, Russell NS, Janus C, et al. 2012 FGFR2 genotype and risk of radiation-associated breast cancer in Hodgkin lymphoma. Blood 119 1029-1031. (doi:10.1182/blood-2011-10383380) 
Marees T, Moll AC, Imhof SM, de Boer MR, Ringens PJ \& van Leeuwen FE 2008 Risk of second malignancies in survivors of retinoblastoma: more than 40 years of follow-up. Journal of the National Cancer Institute 100 1771-1779. (doi:10.1093/jnci/djn394)

Maule M, Scelo G, Pastore G, Brennan P, Hemminki K, Tracey E, Sankila R, Weiderpass E, Olsen JH, McBride ML, et al. 2007 Risk of second malignant neoplasms after childhood leukemia and lymphoma: an international study. Journal of the National Cancer Institute 99 790-800. (doi:10.1093/jnci/djk180)

Maule M, Scelo G, Pastore G, Brennan P, Hemminki K, Pukkala E, Weiderpass E, Olsen JH, Tracey E, McBride ML, et al. 2008 Risk of second malignant neoplasms after childhood central nervous system malignant tumours: an international study. European Journal of Cancer 44 830-839. (doi:10.1016/j.ejca.2008.02.012)

Maule M, Scelo G, Pastore G, Brennan P, Hemminki K, Olsen JH Tracey E, Pukkala E, Weiderpass E, Brewster DH, et al. 2011 Second malignancies after childhood noncentral nervous system solid cancer: results from 13 cancer registries. International Journal of Cancer 129 1940-1952. (doi:10.1002/ijc.26135)

Meadows AT, Friedman DL, Neglia JP, Mertens AC, Donaldson SS, Stovall M, Hammond S, Yasui Y \& Inskip PD 2009 Second neoplasms in survivors of childhood cancer: findings from the Childhood Cancer Survivor Study cohort. Journal of Clinical Oncology $272356-$ 2362. (doi:10.1200/JCO.2008.21.1920)

Mertens AC, Liu Q, Neglia JP, Wasilewski K, Leisenring W, Armstrong GT, Robison LL \& Yasui Y 2008 Cause-specific late mortality among 5-year survivors of childhood cancer: the Childhood Cancer Survivor Study. Journal of the National Cancer Institute 100 1368-1379. (doi:10.1093/jnci/djn310)

Metayer C, Lynch CF, Clarke EA, Glimelius B, Storm H, Pukkala E, Joensuu T, van Leeuwen FE, van't Veer MB, Curtis RE, et al. 2000 Second cancers among long-term survivors of Hodgkin's disease diagnosed in childhood and adolescence. Journal of Clinical Oncology 18 2435-2443.

Moskowitz CS, Chou JF, Wolden SL, Bernstein JL, Malhotra J, Novetsky Friedman D, Mubdi NZ, Leisenring WM, Stovall M, Hammond S, et al. 2014 Breast cancer after chest radiation therapy for childhood cancer. Journal of Clinical Oncology 32 2217-2223. (doi:10.1200/ JCO.2013.54.4601)

Moskowitz CS, Malhotra J, Chou JF, Wolden SL, Weathers RE, Stovall M, Armstrong GT, Leisenring WM, Neglia JP, Robison LL, et al. 2015 Breast cancer following spinal irradiation for a childhood cancer: a report from the Childhood Cancer Survivor Study. Radiotherapy and Oncology 117 213-216.

National Collaborating Centre for Women's and Children's Health 2015 Management of premature ovarian insufficiency. In Menopause: Full Guideline. London, UK: National Collaborating Centre for Women's and Children's Health.

Ness KK, Leisenring W, Goodman P, Kawashima T, Mertens AC, Oeffinger KC, Armstrong GT \& Robison LL 2009 Assessment of selection bias in clinic-based populations of childhood cancer survivors: a report from the childhood cancer survivor study. Pediatric Blood \& Cancer 52 379-386.

Ng AK, Bernardo MV, Weller E, Backstrand K, Silver B, Marcus KC, Tarbell NJ, Stevenson MA, Friedberg JW \& Mauch PM 2002 Second malignancy after Hodgkin disease treated with radiation therapy with or without chemotherapy: long-term risks and risk factors. Blood 100 1989-1996. (doi:10.1182/blood-2002-02-0634)

Ng AK, Kenney LB, Gilbert ES \& Travis LB 2010 Secondary malignancies across the age spectrum. Seminars in Radiation Oncology 20 67-78.

Ng AK, Garber JE, Diller LR, Birdwell RL, Feng Y, Neuberg DS, Silver B, Fisher DC, Marcus KJ \& Mauch PM 2013 Prospective study of the efficacy of breast magnetic resonance imaging and mammographic screening in survivors of Hodgkin lymphoma. Journal of Clinical Oncology 31 2282-2288. (doi:10.1200/JCO.2012.46.5732)
Nichols KE, Heath JA, Friedman D, Biegel JA, Ganguly A, Mauch P \& Diller L 2003 TP53, BRCA1, and BRCA2 tumor suppressor genes are not commonly mutated in survivors of Hodgkin's disease with second primary neoplasms. Journal of Clinical Oncology 214505 4509. (doi:10.1200/JCO.2003.12.042)

Nogueira CR \& Brentani MM 1996 Triiodothyronine mimics the effects of estrogen in breast cancer cell lines. Journal of Steroid Biochemistry and Molecular Biology 59 271-279. (doi:10.1016/S0960-0760(96)00117-3)

O'Brien MM, Donaldson SS, Balise RR, Whittemore AS \& Link MP 2010 Second malignant neoplasms in survivors of pediatric Hodgkin's lymphoma treated with low-dose radiation and chemotherapy. Journal of Clinical Oncology 28 1232-1239. (doi:10.1200/ JCO.2009.24.8062)

O’Flynn EA, Wilson R, Nerurkar A, Johnston SR \& Allen SD 2011 Metastatic breast cancer in a young adult man after total-body irradiation for acute lymphoblastic leukemia. Journal of Clinical Oncology 29 e607-e609.

Oeffinger KC, Mertens AC, Sklar CA, Kawashima T, Hudson MM, Meadows AT, Friedman DL, Marina N, Hobbie W, Kadan-Lottick NS, et al. 2006 Chronic health conditions in adult survivors of childhood cancer. New England Journal of Medicine 355 1572-1582. (doi:10.1056/NEJMsa060185)

Olsen JH, Moller T, Anderson H, Langmark F, Sankila R, Tryggvadottir L, Winther JF, Rechnitzer C, Jonmundsson G, Christensen J, et al. 2009 Lifelong cancer incidence in 47,697 patients treated for childhood cancer in the Nordic countries. Journal of the National Cancer Institute 101 806-813. (doi:10.1093/jnci/djp104)

Pilarski R \& Nagy R 2012 Genetic testing by cancer site: endocrine system. Cancer Journal 18 364-371. (doi:10.1097/ PPO.0b013e3182609458)

Portulano C, Paroder-Belenitsky M \& Carrasco N 2014 The Na+/Isymporter (NIS): mechanism and medical impact. Endocrine Reviews 35 106-149. (doi:10.1210/er.2012-1036)

Prinzi N, Baldini E, Sorrenti S, De Vito C, Tuccilli C, Catania A, Carbotta S, Mocini R, Coccaro C, Nesca A, et al. 2014 Prevalence of breast cancer in thyroid diseases: results of a cross-sectional study of 3,921 patients. Breast Cancer Research and Treatment 144 683-688.

Reulen RC, Taylor AJ, Winter DL, Stiller CA, Frobisher C, Lancashire ER, McClanahan FM, Sugden EM, Hawkins MM \& British Childhood Cancer Survivor Study. The British Childhood Cancer Survivor Study Steering Group 2008 Long-term population-based risks of breast cancer after childhood cancer. International Journal of Cancer 123 2156-2163.

Reulen RC, Winter DL, Frobisher C, Lancashire ER, Stiller CA, Jenney ME, Skinner R, Stevens MC, Hawkins MM \& British Childhood Cancer Survivor Study Steering Group 2010 Long-term cause-specific mortality among survivors of childhood cancer. JAMA 304 172-179.

Reulen RC, Frobisher C, Winter DL, Kelly J, Lancashire ER, Stiller CA, Pritchard-Jones K, Jenkinson HC, Hawkins MM \& British Childhood Cancer Survivor Study Steering Group 2011 Long-term risks of subsequent primary neoplasms among survivors of childhood cancer. JAMA 305 2311-2319. (doi:10.1001/jama.2011.747)

Robison LL, Mertens AC, Boice JD, Breslow NE, Donaldson SS, Green DM, Li FP, Meadows AT, Mulvihill JJ, Neglia JP, et al. 2002 Study design and cohort characteristics of the Childhood Cancer Survivor Study: a multi-institutional collaborative project. Medical and Pediatric Oncology 38 229-239. (doi:10.1002/mpo.1316)

Schaapveld M, Aleman BM, van Eggermond AM, Janus CP, Krol AD, van der Maazen RW, Roesink J, Raemaekers JM, de Boer JP, Zijlstra JM, et al. 2015 Second cancer risk up to 40 years after treatment for Hodgkin's lymphoma. New England Journal of Medicine 373 24992511. (doi:10.1056/NEJMoa1505949)

Shiovitz S \& Korde LA 2015 Genetics of breast cancer: a topic in evolution. Annals of Oncology 26 1291-1299.

Siegel DA, King J, Tai E, Buchanan N, Ajani UA \& Li J 2014 Cancer incidence rates and trends among children and adolescents in the United States, 2001-2009. Pediatrics 134 e945-e955. 
Sigurdson AJ, Ronckers CM, Mertens AC, Stovall M, Smith SA, Liu Y, Berkow RL, Hammond S, Neglia JP, Meadows AT, et al. 2005 Primary thyroid cancer after a first tumour in childhood (the Childhood Cancer Survivor Study): a nested case-control study. Lancet $\mathbf{3 6 5}$ 2014-2023. (doi:10.1016/S0140-6736(05)66695-0)

Silva JM, Dominguez G, Gonzalez-Sancho JM, Garcia JM, Silva J, GarciaAndrade C, Navarro A, Munoz A \& Bonilla F 2002 Expression of thyroid hormone receptor/erbA genes is altered in human breast cancer. Oncogene 21 4307-4316. (doi:10.1038/sj.onc.1205534)

Sklar C 2005 Maintenance of ovarian function and risk of premature menopause related to cancer treatment. Journal of the National Cancer Institute Monographs 34 25-27. (doi:10.1093/jncimonographs/lgi018)

Socie G, Curtis RE, Deeg HJ, Sobocinski KA, Filipovich AH, Travis LB, Sullivan KM, Rowlings PA, Kingma DW, Banks PM, et al. 2000 New malignant diseases after allogeneic marrow transplantation for childhood acute leukemia. Journal of Clinical Oncology 18 348-357.

Socie G, Baker KS \& Bhatia S 2012 Subsequent malignant neoplasms after hematopoietic cell transplantation. Biology of Blood and Marrow Transplantation 18 S139-S150.

Somerville HM, Steinbeck KS, Stevens G, Delbridge LW, Lam AH \& Stevens MM 2002 Thyroid neoplasia following irradiation in adolescent and young adult survivors of childhood cancer. Medical Journal of Australia 176 584-587.

Steliarova-Foucher E, Stiller C, Kaatsch P, Berrino F, Coebergh JW, Lacour B \& Parkin M 2004 Geographical patterns and time trends of cancer incidence and survival among children and adolescents in Europe since the 1970s (the ACCISproject): an epidemiological study. Lancet 364 2097-2105.

Strahm B \& Malkin D 2006 Hereditary cancer predisposition in children: genetic basis and clinical implications. International Journal of Cancer 119 2001-2006. (doi:10.1002/ijc.21962)

Svahn-Tapper G, Garwicz S, Anderson H, Shamsaldin A, De Vathaire F, Olsen JH, Dollner H, Hertz H, Jonmundsson G, Langmark F, et al. 2006 Radiation dose and relapse are predictors for development of second malignant solid tumors after cancer in childhood and adolescence: a population-based case-control study in the five Nordic countries. Acta Oncologica 45 438-448. (doi:10.1080/02841860600658633)

Swerdlow AJ, Cooke R, Bates A, Cunningham D, Falk SJ, Gilson D, Hancock BW, Harris SJ, Horwich A, Hoskin PJ, et al. 2012 Breast cancer risk after supradiaphragmatic radiotherapy for Hodgkin's lymphoma in England and Wales: a National Cohort Study. Journal of Clinical Oncology 30 2745-2752. (doi:10.1200/JCO.2011.38.8835)

Takahashi M, Saenko VA, Rogounovitch TI, Kawaguchi T, Drozd VM, Takigawa-Imamura H, Akulevich NM, Ratanajaraya C, Mitsutake N, Takamura N, et al. 2010 The FOXE1 locus is a major genetic determinant for radiation-related thyroid carcinoma in Chernobyl. Human Molecular Genetics 19 2516-2523. (doi:10.1093/hmg/ddq123)

Taylor AJ, Winter DL, Stiller CA, Murphy M \& Hawkins MM 2007 Risk of breast cancer in female survivors of childhood Hodgkin's disease in Britain: a population-based study. International Journal of Cancer 120 384-391. (doi:10.1002/ijc.22261)

Taylor AJ, Winter DL, Pritchard-Jones K, Stiller CA, Frobisher C, Lancashire ER, Reulen RC, Hawkins MM \& British Childhood Cancer Survivor S 2008 Second primary neoplasms in survivors of Wilms' tumour--a population-based cohort study from the British Childhood Cancer Survivor Study. International Journal of Cancer 122 2085-2093. (doi:10.1002/ijc.23333)

Taylor AJ, Croft AP, Palace AM, Winter DL, Reulen RC, Stiller CA, Stevens MC \& Hawkins MM 2009 Risk of thyroid cancer in survivors of childhood cancer: results from the British Childhood Cancer Survivor Study. International Journal of Cancer 125 2400-2405. (doi:10.1002/ijc.24581)
Travis LB, Gospodarowicz M, Curtis RE, Clarke EA, Andersson M, Glimelius B, Joensuu T, Lynch CF, van Leeuwen FE, Holowaty E, et al. 2002 Lung cancer following chemotherapy and radiotherapy for Hodgkin's disease. Jounal of the National Cancer Institute $\mathbf{9 4}$ 182-192. (doi:10.1093/jnci/94.3.182)

Travis LB, Hill DA, Dores GM, Gospodarowicz M, van Leeuwen FE, Holowaty E, Glimelius B, Andersson M, Wiklund T, Lynch CF, et al. 2003 Breast cancer following radiotherapy and chemotherapy among young women with Hodgkin disease. JAMA 290 465-475. (doi:10.1001/jama.290.4.465)

Travis LB, Hill D, Dores GM, Gospodarowicz M, van Leeuwen FE, Holowaty E, Glimelius B, Andersson M, Pukkala E, Lynch CF, et al. 2005 Cumulative absolute breast cancer risk for young women treated for Hodgkin lymphoma. Jounal of the National Cancer Institute 97 1428-1437. (doi:10.1093/jnci/dji290)

Tucker MA, Jones PH, Boice JD Jr, Robison LL, Stone BJ, Stovall M, Jenkin RD, Lubin JH, Baum ES, Siegel SE, et al. 1991 Therapeutic radiation at a young age is linked to secondary thyroid cancer. The Late Effects Study Group. Cancer Research 51 2885-2888.

van Beek RD, van den Heuvel-Eibrink MM, Hakvoort-Cammel FG, van den Bos C, van der Pal HJ, Krenning EP, de Rijke YB, Pieters R \& de Muinck Keizer-Schrama SM 2009 Bone mineral density, growth, and thyroid function in long-term survivors of pediatric Hodgkin's lymphoma treated with chemotherapy only. Journal of Clinical Endocrinology and Metabolism 94 1904-1909. (doi:10.1210/jc.2008-0622)

van Dorp W, van Beek RD, Laven JS, Pieters R, de Muinck KeizerSchrama SM \& van den Heuvel-Eibrink MM 2012 Long-term endocrine side effects of childhood Hodgkin's lymphoma treatment: a review. Human Reproduction Update 18 12-28. (doi:10.1093/ humupd/dmr038)

van Leeuwen FE, Klokman WJ, Stovall M, Dahler EC, van't Veer MB, Noordijk EM, Crommelin MA, Aleman BM, Broeks A, Gospodarowicz M, et al. 2003 Roles of radiation dose, chemotherapy, and hormonal factors in breast cancer following Hodgkin's disease. Journal of the National Cancer Institute 95 971-980. (doi:10.1093/ jnci/95.13.971)

van Leeuwen FE \& Ronckers CM 2016 Anthracyclines and alkylating agents: new risk factors for breast cancer in childhood cancer survivors? Journal of Clinical Oncology 34 891-894. (doi:10.1200/ JCO.2015.65.0465)

Veiga LH, Bhatti P, Ronckers CM, Sigurdson AJ, Stovall M, Smith SA, Weathers R, Leisenring W, Mertens AC, Hammond S, et al. 2012a Chemotherapy and thyroid cancer risk: a report from the childhood cancer survivor study. Cancer Epidemiology, Biomarkers \& Prevention 21 92-101.

Veiga LH, Lubin JH, Anderson H, de Vathaire F, Tucker M, Bhatti P, Schneider A, Johansson R, Inskip P, Kleinerman R, et al. 2012b A pooled analysis of thyroid cancer incidence following radiotherapy for childhood cancer. Radiation Research 178 365-376.

Vivanco M, Dalle JH, Alberti C, Lescoeur B, Yakouben K, Carel JC, Baruchel A \& Leger J 2012 Malignant and benign thyroid nodules after total body irradiation preceding hematopoietic cell transplantation during childhood. European Journal of Endocrinology 167 225-233.

Zhang J, Walsh MF, Wu G, Edmonson MN, Gruber TA, Easton J, Hedges D, Ma X, Zhou X, Yergeau DA, et al. 2015 Germline mutations in predisposition genes in pediatric cancer. New England Journal of Medicine 374 1390-1391.

Zuccolo L, Pastore G, Pearce N, Mosso ML, Merletti F \& Magnani C 2007 Mortality from cancer and other causes in parents of children with cancer: a population-based study in Piedmont, Italy. European Journal of Cancer Prevention 16 390-395.

Received in final form 19 May 2016

Accepted 26 May 2016

Accepted Preprint published online 26 May 2016 http://erc.endocrinology-journals.org DOI: 10.1530/ERC-16-0113
C 2016 Society for Endocrinology Printed in Great Britain
Published by Bioscientifica Ltd. 